\title{
The Size-dependent Cytotoxicity of Amorphous Silica Nanoparticles: A Systematic Review of in vitro Studies
}

This article was published in the following Dove Press journal: International Journal of Nanomedicine

\author{
Xuemeng Dong' \\ Zehao $\mathrm{Wu}^{\prime}$ \\ Xiuping $\mathrm{Li}^{\mathrm{I}}$ \\ Liyan Xiao' \\ Man Yang ${ }^{1,2}$ \\ Yang $\mathrm{Li}^{1,2}$ \\ Junchao Duan ${ }^{1,2}$ \\ Zhiwei Sun ${ }^{1,2}$
}

'School of Public Health, Capital Medical University, Beijing 100069, People's Republic of China; ${ }^{2}$ Beijing Key Laboratory of Environmental Toxicology, Capital Medical University, Beijing 100069, People's Republic of China
Correspondence: Zhiwei Sun; Yang Li Beijing Key Laboratory of Environmental Toxicology, Capital Medical University, Beijing 100069, People's Republic of China $\mathrm{Tel} / \mathrm{Fax}+8601083911507$;

$+8601083911868$

Email zwsun@ccmu.edu.cn;

li_yang@ccmu.edu.cn

\begin{abstract}
With the increasing production and application of engineered amorphous silica nanoparticles (aSiNPs), people have more opportunities to be exposed to aSiNPs. However, the knowledge of its adverse health effects and related mechanisms is still limited, compared with the well-studied crystalline micron-sized silica. Since small differences in the physicalchemical properties of nanoparticles could cause significant differences in the toxic effect, it is important to distinguish how these variations influence the outcoming toxicity. Notably, particle size, as one of the essential characterizations of aSiNPs, is relevant to its biological activities. Thus, the aim of this systematic review was to summarize the relationship between the particle size of aSiNPs and its adverse biological effects. In order to avoid the influence of complicated in vivo experimental conditions on the toxic outcome, only in vitro toxicity studies which reported on the cytotoxic effect of different sizes aSiNPs were included. After the systematic literature retrieval, selection, and quality assessment process, 76 eligible scientific papers were finally included in this review. There were $76 \%$ of the studies that concluded a size-dependent cytotoxicity of aSiNPs, in which smaller-sized aSiNPs possessed greater toxicity. However, this trend could be modified by certain influence factors, such as the synthetic method of aSiNPs, particle aggregation state in cell culture medium, toxicity endpoint detection method, and some other experimental conditions. The effects of these influence factors on the size-dependent cytotoxicity of aSiNPs were also discussed in detail in the present review.
\end{abstract}

Keywords: silica nanoparticles, particle size, cytotoxicity, cell death, nanotoxicology, influence factors

\section{Introduction}

Silica particles often occur in crystalline and amorphous forms. Compared with crystalline silica, natural amorphous silica is generally considered as less harmful, since the toxicological potential of silica has so far been linked to its crystallinity. ${ }^{1}$ Synthetic amorphous silica nanoparticles (aSiNPs), an attractive engineering nanomaterial, was commonly referred to amorphous silicon dioxide $\left(\mathrm{SiO}_{2}\right)$ with particle size $\leq 100 \mathrm{~nm}$. Contrary to its micron-sized particles, aSiNPs possesses many excellent physical-chemical properties, ${ }^{2}$ and is penetrating into many aspects of people's lives and productions. ${ }^{3}$ According to the Consumer Products Inventory (CPI), there were over 100 commercial products which contained aSiNPs, including foodstuffs, toothpastes, cosmetics, paints, electronic devices, even drugs and vitamins. ${ }^{4}$ Due to its multiple utilizations, aSiNPs has become the second largest 
engineering nanomaterial in terms of annual output. ${ }^{5}$ The large-scale production and widespread application of aSiNPs have increased the risk of human exposure. Thus, the adverse health impact of this kind of nanomaterial on human beings deserves more attention and should be carefully addressed.

The human body can be exposed to aSiNPs through several routes such as inhalation, oral ingestion, transdermal penetration and parenteral injection intentionally or unintentionally. ${ }^{6}$ In the last two decades, numerous studies in vivo and in vitro have evaluated the toxicity and biosafety of aSiNPs, and have demonstrated its potential adverse effects on human health. Several researches in vivo showed that after entering the experimental animal body, aSiNPs could distribute in almost all organs, and cause inflammation as well as tissue damage through direct or indirect ways. ${ }^{7,8}$ Further in vitro mechanism studies reported that aSiNPs could accumulate in cells by both active endocytotic pathway and passive diffusion, and distribute within endocytotic vesicles or freely in cytoplasma and organelles. ${ }^{9}$ Meanwhile, aSiNPs could exert cytotoxicity and genotoxicity in many kinds of cell lines, which was considered through the oxidative stress, endoplasmic reticulum stress, autophagy dysfunction or proinflammatory response induced by the particles. ${ }^{10,11}$

It is well accepted in nanotoxicology that physicalchemical properties of nanomaterials, such as particle size, surface area, morphology, porosity, aggregation state, crystallinity and other characterizations, should be taken into account when assessing the potential toxicity of nanomaterials in biological systems. As to aSiNPs, a large number of studies have confirmed that these properties could influence the adsorption, distribution, excretion as well as cellular internalization of the particles, which were further associated with the toxic effect in vivo and in vitro. ${ }^{12-14}$ Notably, particle size, as an essential characterization of aSiNPs, is relevant to its biological activities. In nanoscale, the extreme small size confers specific large surface area of nanoparticles, which makes the surface atoms or molecules increase exponentially. Therefore, aSiNPs of smaller size possesses larger surface area and higher surface reactivity, which may render it more active chemically and biologically.

The possible biological effect related to aSiNPs exposure of different particle sizes have been widely studied. Researchers indicated that smaller size could facilitate the cellular uptake, tissue penetration and systemic distribution of aSiNPs. ${ }^{13,15}$ In addition, plenty of studies also demonstrated the size dependent toxic effect of aSiNPs - the smaller the particle size was, the greater the toxicity produced. ${ }^{10,16}$ However, due to the complexity of experimental conditions and biological systems, there were still some researchers who reported that larger aSiNPs possessed higher toxicity or that no significant difference was observed between aSiNPs with different particle sizes. ${ }^{17,18}$ Herein, we provided a systematic literature review to summarize the relationship between the particle size of aSiNPs and its adverse biological effect. In order to avoid the influence of complicated experimental conditions in vivo, we only included in vitro studies of cell experiments to analyze the toxic intensity of aSiNPs with different sizes. We also explored the reasons why some studies did not conclude a size-dependent cytotoxicity of aSiNPs, and several influence factors of this trend were extracted and discussed in detail in this review.

\section{Methodology Inclusion Criteria}

In this review, we would like to summarize the relationship between particle size of aSiNPs and its potential cytotoxicity. Firstly, the influence of other characteristics, such as crystallinity, shape, porosity, surface modification and so on, should be eliminated. Hence, only studies using amorphous non-mesoporous sphere silica nanoparticles without any surface modification were included. Secondly, compared with in vitro cell experiment, the internal environment of experimental animals is more complex and more difficult to control. As known, the ADME process and even the toxicity of aSiNPs can be influenced obviously by different exposure routes and complex internal environment, such as the presence of protein, the change of $\mathrm{pH}$ value, the difference of ionic strength and so on. Moreover, it was also difficult to trace the nanoparticles in vivo. Thus, in order to better summarize the size-dependent toxicity of aSiNPs and explore the influence factors of this trend, only in vitro studies assessing cytotoxicity of aSiNPs were included. Finally, we chose cell death as the toxicity endpoint to compare the toxic effect of aSiNPs with different particles, which due to the detection method of cell death is simple, convenient, and repeatable. Overall, according to the purpose of this review, studies should meet the following inclusion criteria otherwise they would be excluded:

(i) Use amorphous non-mesoporous sphere silica nanoparticles without any surface modification; 
(ii) Use different sizes of aSiNPs;

(iii) Primary size of aSiNPs should be reported;

(iv) In vitro cytotoxicity studies;

(v) Toxicological endpoints should include the detection of cell death or cell viability;

(vi) Papers should be published in English.

\section{Literature Search}

A comprehensive literature search was performed to identify studies describing the cytotoxicity of aSiNPs based on the Office of Health Assessment and Translation (OHAT) approach for systematic review and evidence integration. We searched two databases for articles published and indexed from January 1, 2000 to July 30, 2020. In the PubMed (http://www.ncbi.nlm.nih.gov/pubmed) and Web of Science (https://webofknowledge.com/) databases, the following search strategy was used: (TS = "Silica nanoparticle" OR TS = " $\mathrm{SiO}_{2}$ nanoparticle" OR TS = "silicon dioxide nanoparticle" OR TS = "silica nanomaterial" OR TS = " $\mathrm{SiO}_{2}$ nanomaterial" OR TS = "Nano silica" OR TS = "Nano $\mathrm{SiO}_{2}$ ") AND (TS = "Cytotoxic*" OR TS = "Toxic"” OR TS = "Adverse effect"). Therefore, we could retrieve as many articles as possible concerning the toxic effect of aSiNPs. The article retrieval process was summarized in a flow chart as shown in Figure 1.

\section{Quality Assessment and Information Extraction}

Quality assessment of included studies was based on the guideline for assessing quality of in vitro studies as suggested by Samuel et al. ${ }^{19}$ The quality of each study was assessed from 11 items concerning the basic information and experimental design, which were scientific background description, study purpose description, study model justification, study design description, cell culture condition description, endpoint measurement description, endpoint outcome description, statistical method description, dose/concentration response consideration, result interpretation, and discussion, as well as research funding. Each item was scored 1 and the overall score was 11 . Studies were graded as poor quality if they met $\leq 4$ items, fair if they met 5 to 8 items, and good if they met $\geq 9$ items.

Information extraction was performed independently by two reviewers using a predesigned data extraction form. For each study, the following data were extracted:

(i) Basic information of the article: first author and year published;

(ii) ASiNPs characterization: primary particle size and aggregation state;

(iii) Study design: cell type, exposure dose, and exposure time;

(iv) Methodology: detection method of cell viability;

(v) Result: relationship between particle size and cytotoxicity.

\section{Results}

\section{Search Result Description}

We retrieved a list of 4038 and 1543 articles published in PubMed and Web of Science, respectively, using the

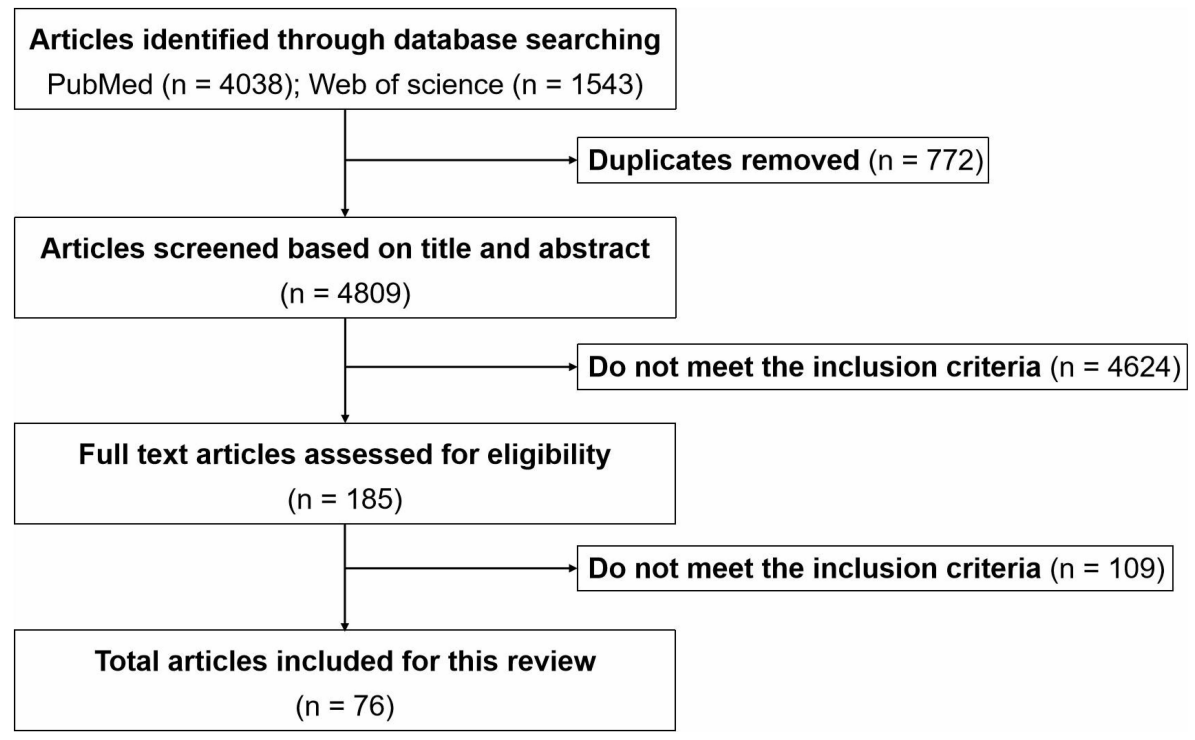

Figure I Flow chart of systematic selection of articles. 
approach described in the methodology section. As shown in Figure 1, after removing duplicates and screening the titles and abstracts, 185 relevant articles were left. Then, another 109 articles that did not meet the inclusion criteria were removed through full text retrieval. Finally, 76 eligible articles reporting the cytotoxicity of aSiNPs with different sizes were selected for this systematic review. All 76 papers had good quality rating and the quality assessment result was shown in Table 1. The information descriptions of included articles were manifested in Table 2, which contains article source, type of cell line, primary size of aSiNPs, exposure dosage, exposure time, detection method of cell death/cell viability, and relationship between particle size and cytotoxicity. As summarized in Figure 2, 76\% of the studies concluded that smaller aSiNPs possessed greater cytotoxicity, while $17 \%$ of the studies obtained the opposite conclusion, and the remaining $7 \%$ studies did not show any significant difference in the toxicity of aSiNPs with different sizes.

\section{Size-dependent Cytotoxicity of aSiNPs Size-dependent Cytotoxicity of aSiNPs on Cell Lines from Respiratory System}

Gonzalez et $\mathrm{al}^{20}$ examined the cytotoxic activity of aSiNPs with three different sizes in human alveolar carcinoma cell line (A549). The $\mathrm{ED}_{50}$ of $16 \mathrm{~nm}, 60 \mathrm{~nm}$ and $104 \mathrm{~nm}$ aSiNPs, determined by the MTT assay after $24 \mathrm{~h}$ exposure, was 45.9 , 48.9, and $165.9 \mu \mathrm{g} / \mathrm{mL}$, respectively, indicating a sizeresponse cytotoxicity of aSiNPs. Fede et $\mathrm{al}^{21}$ also attempted to study the role of size in aSiNPs ( 9 and $18 \mathrm{~nm}$ ) toxicity in A549 cells. Results obtained showed that two sizes of aSiNPs caused very similar cytotoxicity, while the smaller aSiNPs was more effective in inflammatory and apoptosis processes. In the study of Gonzalez et al, ${ }^{22}$ A549 cells were exposed to a series of different sizes of aSiNPs (ranged from 12-174 nm), and a size-dependency of toxicity was observed. The smallest aSiNPs $(12 \mathrm{~nm})$ induced the highest cytotoxicity, especially in the absence of serum. Tokgun et $\mathrm{al}^{23}$ demonstrated that among 6,15 , and $30 \mathrm{~nm}$ sizes of aSiNPs, $6 \mathrm{~nm}$-sized nanoparticles had strongest cytotoxic effects on A549 cells, and this cytotoxicity came from dead receptor-mediated induction of apoptosis. Liu et $\mathrm{al}^{24}$ examined the cell viability of A549 cells after exposing to $\mathrm{SiO}_{2}$ particles at various concentrations $(5,10,20,30,40,60,80$, and $100 \mu \mathrm{g} / \mathrm{mL}$ ). Results of CCK-8 assay showed that exposures of 10-20 nm aSiNPs resulted in significantly decreased viability of A549 cells, while $5 \mu \mathrm{m} \mathrm{SiO}_{2}$ particles did not affect the cell viability obviously. Leibe et $\mathrm{al}^{10}$ analyzed the effects of two aSiNPs on A549 cells, which were $12 \mathrm{~nm}$ aSiNPs produced by flame synthesis and $50 \mathrm{~nm}$ aSiNPs produced by Stöber synthesis. As observed by the LDH release assay, the cytotoxicity induced by pyrogenic $12 \mathrm{~nm}$ aSiNPs was more pronounced than colloidal $50 \mathrm{~nm}$ aSiNPs. In addition, both two kinds of aSiNPs reduced the number of viable cells and provoke cell death only in the absence, but not in the presence of serum.

Wottrich et $\mathrm{al}^{25}$ showed that aSiNPs $(60 \mathrm{~nm}$ and 100 $\mathrm{nm})$ induced dose-dependent and size-related reduction in cell viability of A549 cells and differentiated macrophagelike THP-1 cells. Meanwhile, smaller aSiNPs caused higher IL-6 and IL-8 release in co-culture system of A549 and macrophages (Mono Mac 6 or differentiated THP-1). In the research of Napierska et al, ${ }^{26}$ co-culture of A549 cells and differentiated THP-1 cells were also introduced to elucidate the toxicity and related mechanism of aSiNPs $(2,16,60$, and $104 \mathrm{~nm})$. A size-dependent cytotoxic response to aSiNPs was observed in both cell lines, and $\mathrm{TC}_{50}$ increased with particle size. In addition, the release of pro-inflammatory mediators by endothelial cells after inhalation of aSiNPs could be a possible mechanism of its respiratory toxicity. Panas et $\mathrm{al}^{27}$ explored the toxic effects of $12 \mathrm{~nm}$ and $25 \mathrm{~nm}$ aSiNPs in A549 cells and RAW264.7 mouse macrophage cell line in the presence and absence of serum. Both two particles decreased cell viability of A549 and RAW264.7 cells, and induced pro-inflammatory significantly in the absence of serum. Cytotoxicity of $12 \mathrm{~nm}$ aSiNPs was more prominent than that of $25 \mathrm{~nm}$. Conversely, the toxicity was completely suppressed in the presence of serum.

Li et $\mathrm{al}^{28,29}$ investigated the possible cytotoxicity of three sizes of aSiNPs $(40,60$, and $200 \mathrm{~nm})$ in human bronchial epithelial BEAS-2B cells. These particles inhibited the cell viability in a size-dependent manner, the smaller aSiNPs produced higher toxic effect. Låg et al ${ }^{30}$ studied the toxicity of $10 \mathrm{~nm}$ and $50 \mathrm{~nm}$ aSiNPs using two different human bronchial epithelial cell lines (BEAS-2B and HBEC3-KT). As measured by the LDH release assay, the cell viability was reduced approximately $50 \%$ after exposing to $50 \mu \mathrm{g} / \mathrm{mL}$ of $10 \mathrm{~nm}$ aSiNPs for $20 \mathrm{~h}$ in both cell types and $10-25 \%$ after exposing to $200 \mu \mathrm{g} / \mathrm{mL} 50 \mathrm{~nm}$ aSiNPs. Thus, $10 \mathrm{~nm}$ aSiNPs was far more cytotoxic than $50 \mathrm{~nm}$ aSiNPs. Kasper et $\mathrm{al}^{31}$ examined the cytotoxicity of different-sized aSiNPs (30, 70, and $300 \mathrm{~nm}$ ) on lung epithelial cells line NCI H441 as well as endothelial cell line ISO-HAS-1, and illustrated a clearly increased toxicity of the smaller-sized aSiNPs. McCarthy et $\mathrm{al}^{32}$ studied 


\begin{tabular}{|c|c|}
\hline 㒾 & 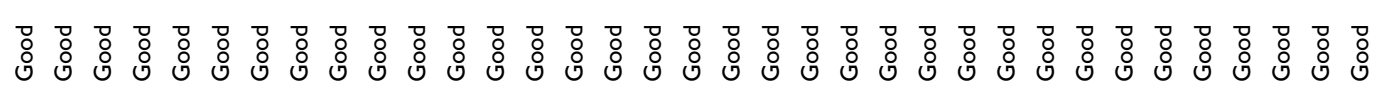 \\
\hline$\stackrel{0}{\grave{\vdots}}$ & 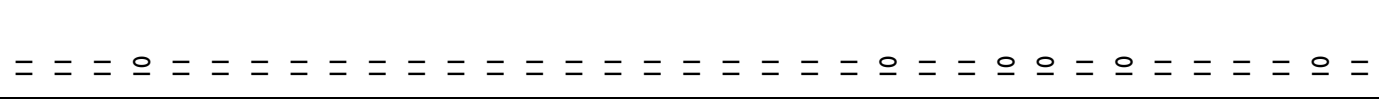 \\
\hline 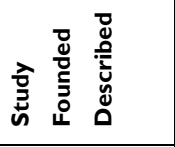 & 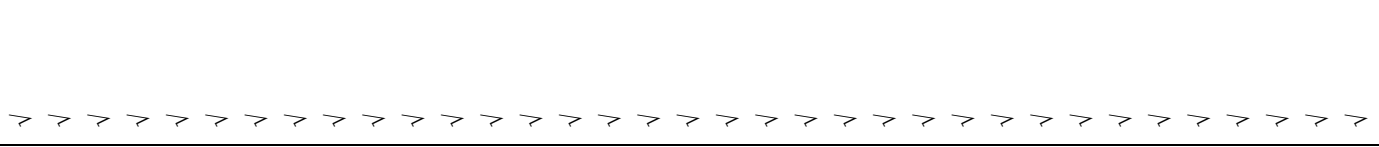 \\
\hline 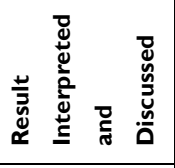 & $p>p>p>p>p>p>p>p>p>p>p>p>p>p>p>p>p>p$ \\
\hline 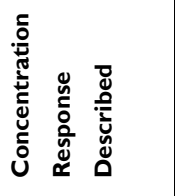 & 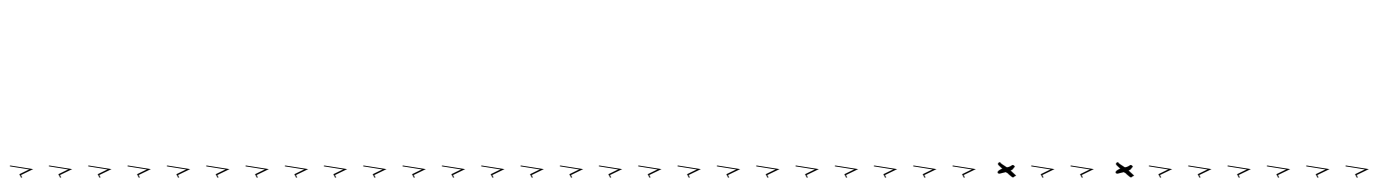 \\
\hline 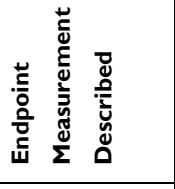 & 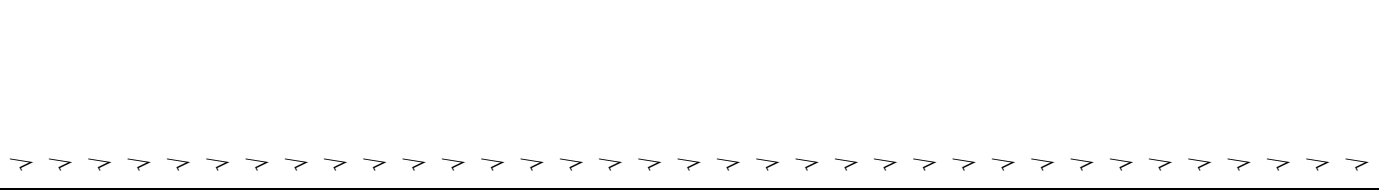 \\
\hline 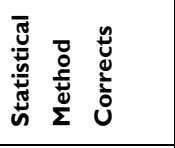 & 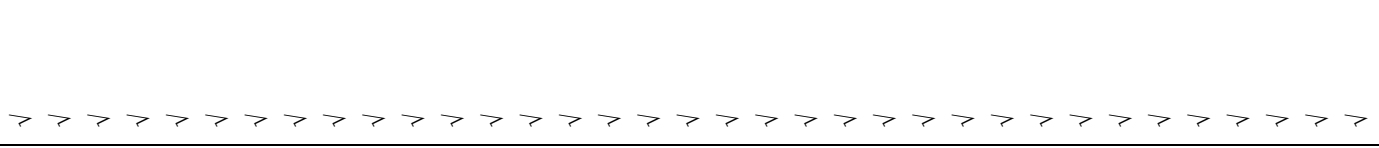 \\
\hline 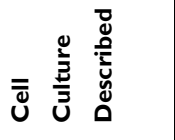 & 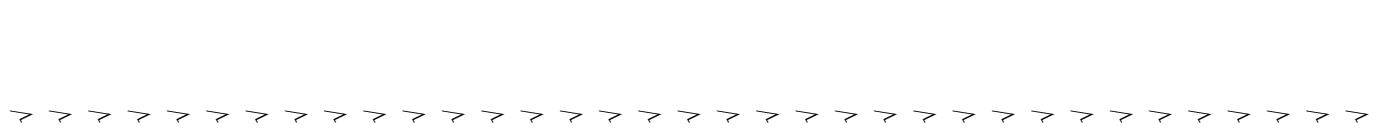 \\
\hline 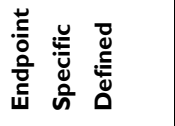 & 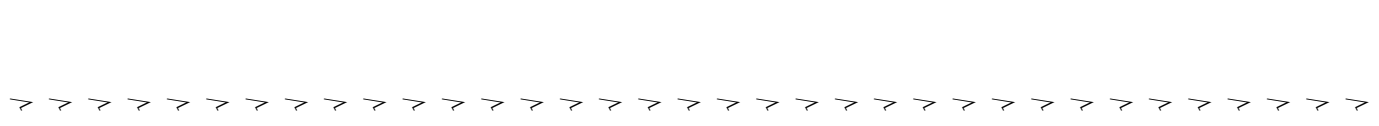 \\
\hline 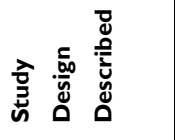 & 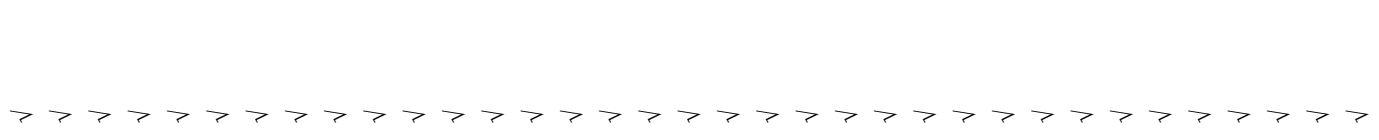 \\
\hline 套 总 & 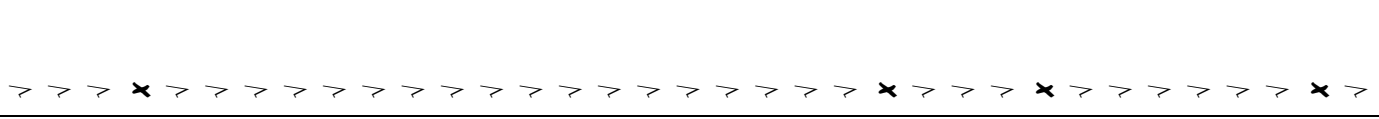 \\
\hline 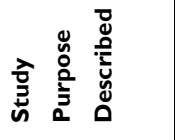 & 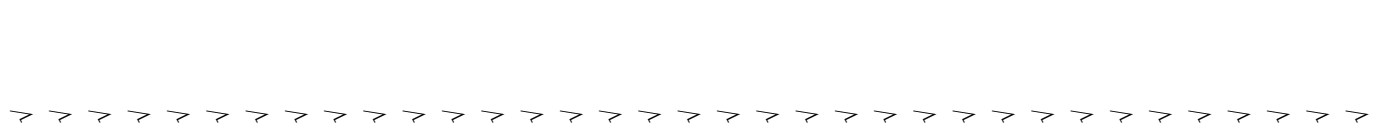 \\
\hline 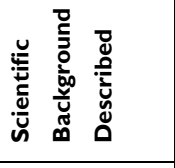 & 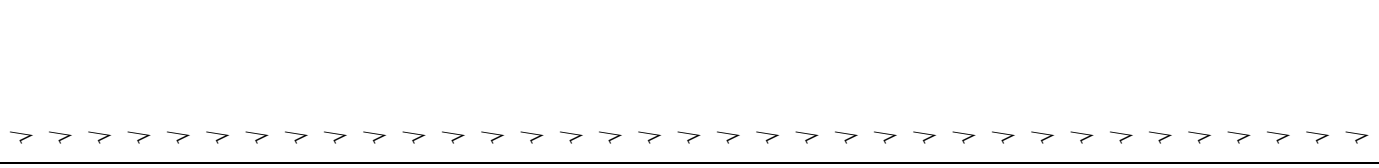 \\
\hline$\stackrel{\longleftarrow}{\grave{\nu}}$ & 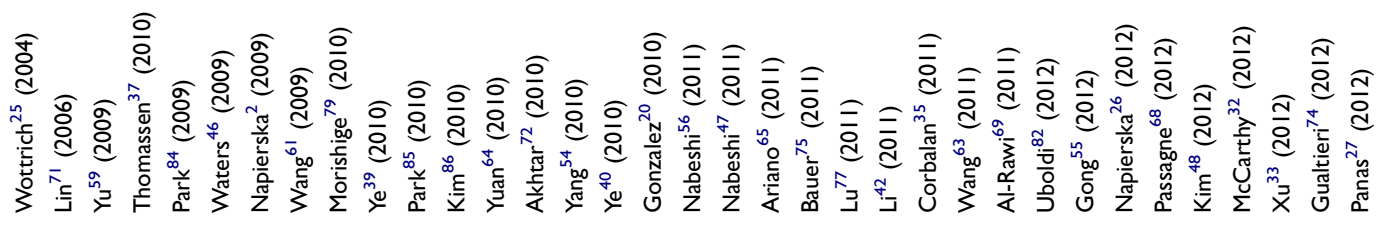 \\
\hline
\end{tabular}




\begin{tabular}{|c|c|}
\hline 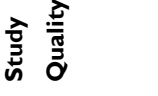 & 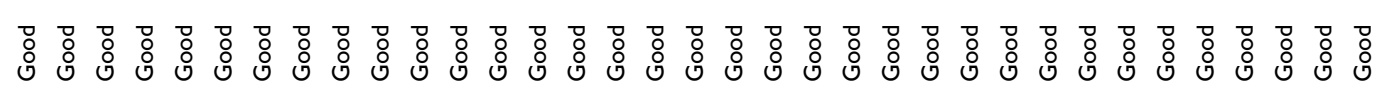 \\
\hline ڤ̆ & $\circ===$ = \\
\hline 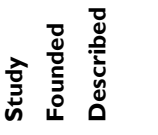 & 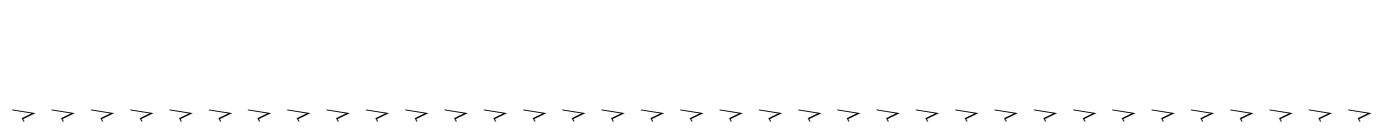 \\
\hline 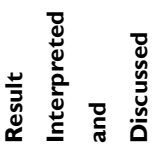 & 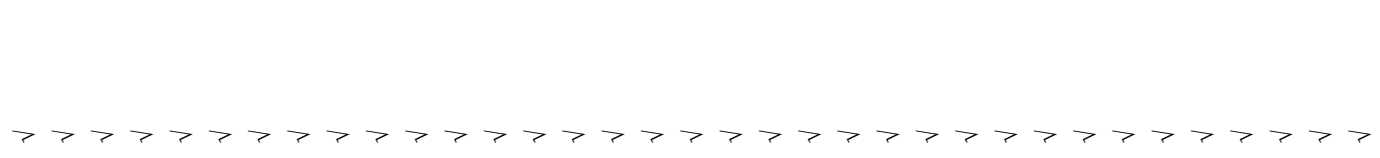 \\
\hline 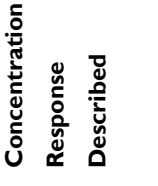 & 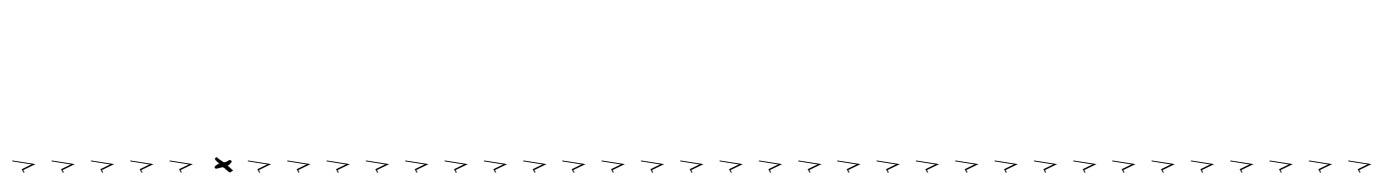 \\
\hline 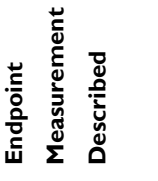 & 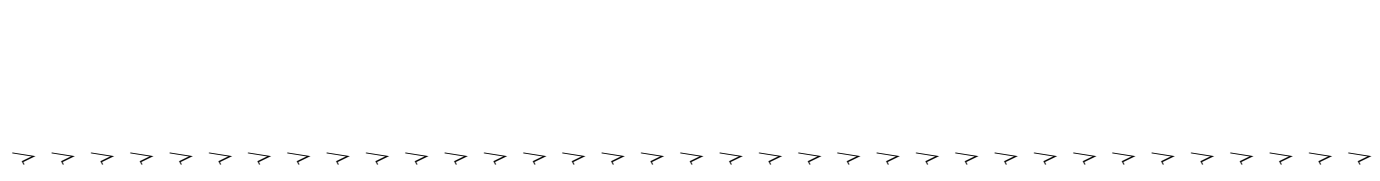 \\
\hline 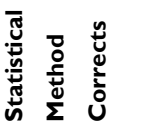 & 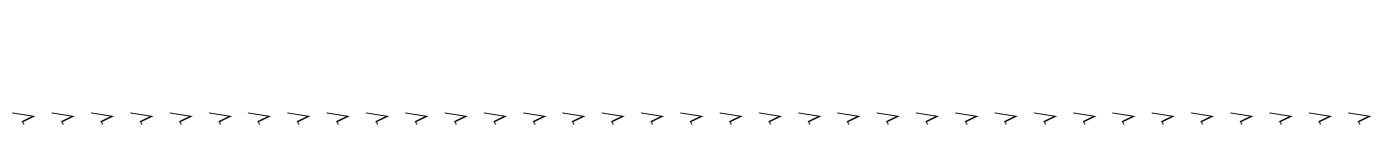 \\
\hline 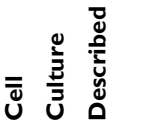 & 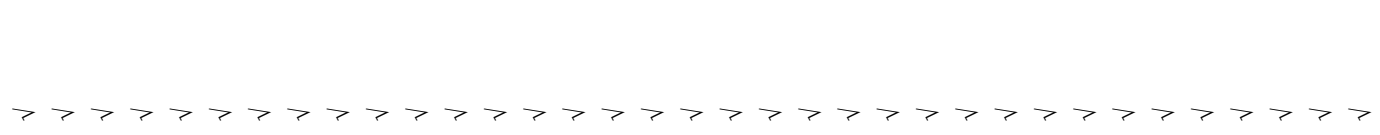 \\
\hline 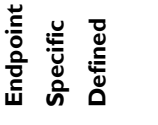 & 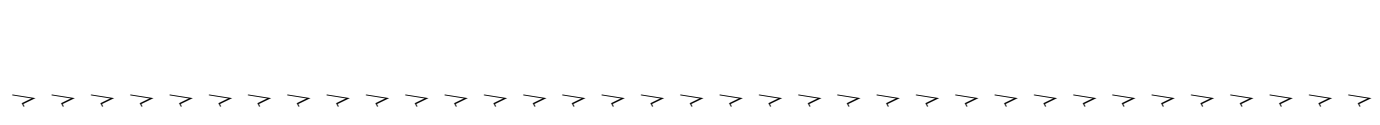 \\
\hline 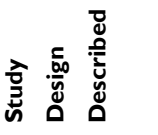 & 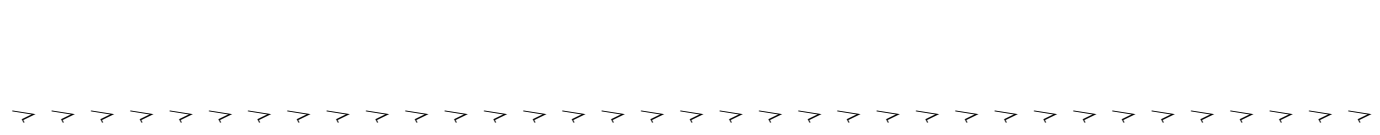 \\
\hline ते̀ & 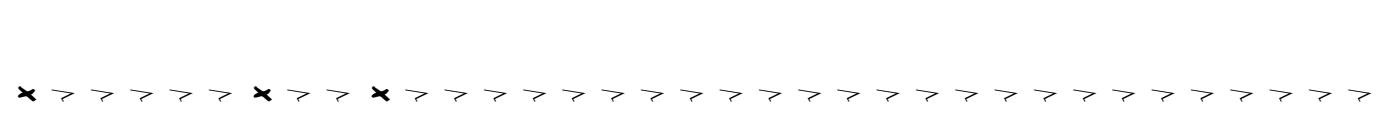 \\
\hline 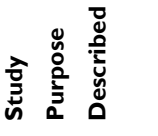 & 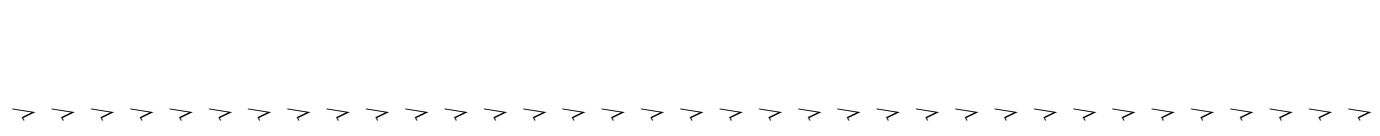 \\
\hline 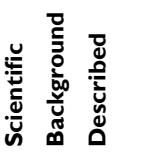 & 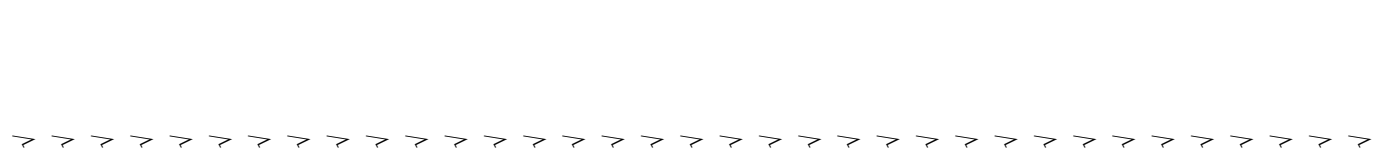 \\
\hline 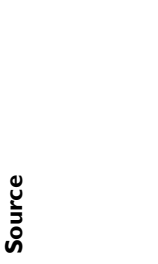 & 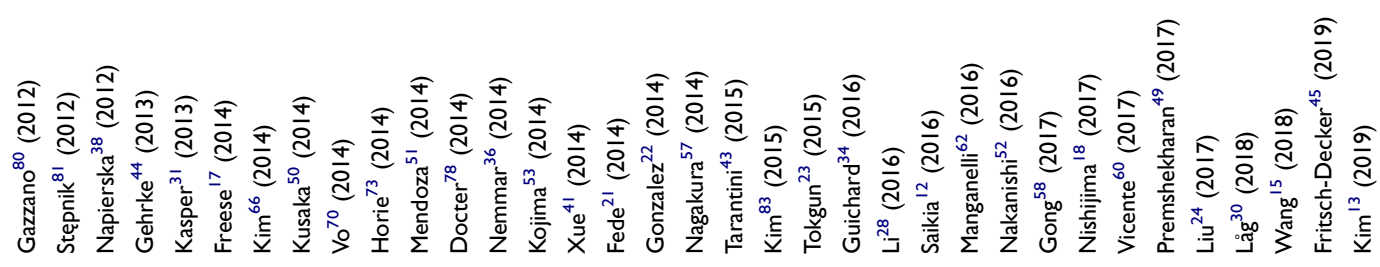 \\
\hline
\end{tabular}




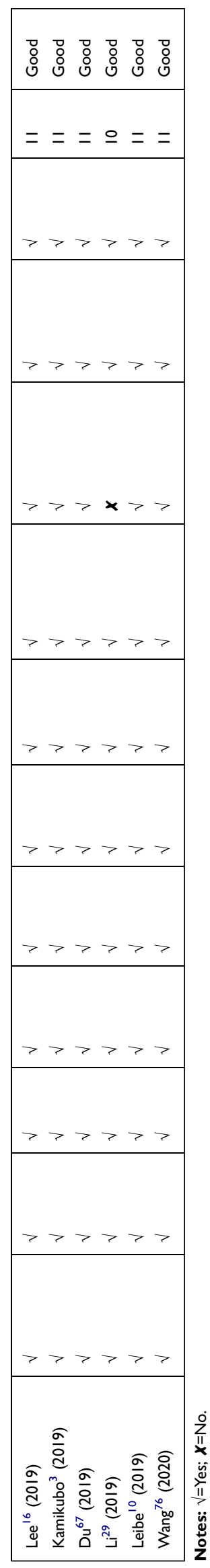

the effects of exposing human lung adenocarcinoma cells (Calu-3) to aSiNPs of various sizes (10, 150, and $500 \mathrm{~nm}$ ). Ten nanometer aSiNPs was found to induce cytotoxicity in a time and concentration-dependent way, while larger nanoparticles $(150$ and $500 \mathrm{~nm}$ ) were not found to be cytotoxic even at high concentrations. $\mathrm{Xu}$ et $\mathrm{al}^{33}$ exposed human lung fibroblasts (HFL-Is) to $20 \mathrm{~nm}$ and $80 \mathrm{~nm}$ aSiNPs. Results of the cell viability, the ratio of apoptosis and the pathway of cell injury demonstrated that a sizeassociated and a dose-dependent toxicity on HFL-Is was induced by aSiNPs, smaller sizes and higher concentrations of aSiNPs seemed more cytotoxic. Guichard et $\mathrm{al}^{34}$ aimed to compare the cytotoxicity and genotoxicity of five representative manufactured aSiNPs samples (Pyr 20, Pyr 25/70, Pre 20, Col 15 and Col 40/80) in Chinese hamster lung fibroblasts (V79 cells). Results showed that the finer aSiNPs samples were more cytotoxic than the coarser samples. The cytotoxicity of aSiNPs in V79 cells can be ranked as follows: Col $15(15 \mathrm{~nm})>$ Pyr $20(19 \mathrm{~nm})=$ Pre $20(19 \mathrm{~nm})>\operatorname{Pyr} 25 / 70(25$ and $70 \mathrm{~nm})=\mathrm{Col} 40 / 80(38$ and $79 \mathrm{~nm})$.

Size-dependent Cytotoxicity of aSiNPs on Cell Lines from Cardiovascular System

Corbalan et $\mathrm{al}^{35}$ described that exposures of primary human umbilical vein endothelial cells (HUVECs) to aSiNPs $(10,50,150,500 \mathrm{~nm})$ led to increased cell death. The smallest aSiNPs $(10 \mathrm{~nm})$ induced the highest cytotoxicity, while larger aSiNPs $(50,150$, and $500 \mathrm{~nm}$ ) showed very limited or even no cytotoxicity. Nemmar et $\mathrm{al}^{36}$ reported that exposures of HUVECs to aSiNPs (50 and $500 \mathrm{~nm}$ ) showed a reduced cellular viability, and $50 \mathrm{~nm}$ aSiNPs led to more pronounced toxic effects than that with $500 \mathrm{~nm}$ aSiNPs. In the study of Wang et al, ${ }^{15}$ the potential of four sizes of aSiNPs $(10,25,50,100 \mathrm{~nm})$ to induce the apoptosis of HUVECs was investigated. The results showed that all the four sizes of aSiNPs could significantly elicit apoptosis in HUVECs at the tested concentrations $(1,5,25 \mathrm{mg} / \mathrm{mL})$. Moreover, the apoptotic rates were increased with the elevating levels and decreasing sizes of administrative aSiNPs, showing both doseand size-dependent effect relationships. In the research of Lee et al, ${ }^{16}$ HUVECs were treated with various concentrations $(5-25 \mu \mathrm{g} / \mathrm{mL})$ of aSiNPs $(20,30,40$, and $50 \mathrm{~nm})$ for $24 \mathrm{~h}$. Result of apoptosis and/or necrosis assessment showed that aSiNPs of $20 \mathrm{~nm}$ in size, but not those of 30 $\mathrm{nm}, 40 \mathrm{~nm}$, and $50 \mathrm{~nm}$ in size, induced significant decreases in cellular viability. 
Table 2 In vitro Studies on Cytotoxicity of Amorphous Silica Nanoparticles (aSiNPs) with Different Sizes

\begin{tabular}{|c|c|c|c|c|c|c|c|}
\hline Source & Cell Type & $\begin{array}{l}\text { Particle } \\
\text { Primary Size }\end{array}$ & $\begin{array}{l}\text { Aggregates/ } \\
\text { Agglomerates }\end{array}$ & Exposure Dose & $\begin{array}{l}\text { Exposure } \\
\text { Time }\end{array}$ & $\begin{array}{l}\text { Assay(s)/ } \\
\text { Method(s) }\end{array}$ & $\begin{array}{l}\text { Size-dependent } \\
\text { Cytotoxicity }\end{array}$ \\
\hline $\begin{array}{l}\text { Wottrich }{ }^{25} \\
(2004)\end{array}$ & $\begin{array}{l}\text { A549 } \\
\text { THP-I } \\
\text { Mono Mac } 6\end{array}$ & $\mathrm{~S}-60,100 \mathrm{~nm}$ & - & $10-200 \mu \mathrm{g} / \mathrm{mL}$ & $24 \mathrm{~h}$ & $\begin{array}{l}\text { LDH activity } \\
\text { assay }\end{array}$ & $\begin{array}{l}\text { Cytotoxicity: } 60 \\
\mathrm{~nm}>100 \mathrm{~nm}\end{array}$ \\
\hline $\operatorname{Lin}^{71}(2006)$ & A549 & $15,46 \mathrm{~nm}$ & $\sqrt{ }$ & $10-100 \mu g / m L$ & $24,48,72 \mathrm{~h}$ & $\begin{array}{l}\text { LDH activity } \\
\text { assay and } \\
\text { Sulforhod } \\
\text { amine } \\
\text { B assay(SRB) }\end{array}$ & Not significant \\
\hline $\mathrm{Yu}^{59}$ (2009) & HEL-30 cells & $\begin{array}{l}\mathrm{S}-30,48,118 \\
535 \mathrm{~nm}\end{array}$ & - & 0-200 $\mu \mathrm{g} / \mathrm{mL}$ & $24 \mathrm{~h}$ & $\begin{array}{l}\text { MTT assay and } \\
\text { LDH activity } \\
\text { assay }\end{array}$ & $\begin{array}{l}\text { Cytotoxicity: } 30 \\
\mathrm{~nm}>48 \mathrm{~nm}>1 \mathrm{l} 8 \\
\mathrm{~nm}>535 \mathrm{~nm}\end{array}$ \\
\hline $\begin{array}{l}\text { Thomassen }{ }^{37} \\
(2010)\end{array}$ & $\begin{array}{l}\text { EAHY926 } \\
J 774\end{array}$ & $\begin{array}{l}\text { Lu-II, I4, I5 } \\
\text { nm } \\
\text { Ly-2, 26, 34, } 36 \\
\text { nm } \\
\text { S-18, 60, 104, } \\
335 \text { nm }\end{array}$ & $\begin{array}{l}\text { No substantial } \\
\text { aggregation, except } \\
\text { for the Ludox-Sil-15, } \\
\text { Stober-Sil-104, } \\
\text { Sober-Sil-18, and } \\
\text { Lys-Sil-2 particles }\end{array}$ & $0-2000 \mu \mathrm{g} / \mathrm{mL}$ & $24 \mathrm{~h}$ & $\begin{array}{l}\text { MTT assay and } \\
\text { WST-I assay }\end{array}$ & $\begin{array}{l}\text { The smaller the } \\
\text { particle size, the } \\
\text { greater the } \\
\text { cytotoxicity. }\end{array}$ \\
\hline Park $^{84}$ (2009) & D3 & $\begin{array}{l}S-10,30,80, \\
400 \mathrm{~nm}\end{array}$ & $\begin{array}{l}\text { No substantial } \\
\text { aggregation, except } \\
\text { for the } 10 \mathrm{~nm} \\
\text { particles }\end{array}$ & $0.3-100 \mu g / m L$ & $\begin{array}{l}24 \mathrm{~h}, 10 \\
\text { days }\end{array}$ & WST-I assay & $\begin{array}{l}\text { Not significant; } \\
\text { cytotoxicity: } 30 \\
\mathrm{~nm}>10 \mathrm{~nm}>80 \\
\mathrm{~nm} \text { and } 400 \mathrm{~nm}\end{array}$ \\
\hline Waters $^{46}(2009)$ & RAW 264.7 & $\begin{array}{l}\text { P-10, 50, I50, } \\
300,500 \mathrm{~nm} \\
\text { Lu-7, } 16 \mathrm{~nm}\end{array}$ & $\begin{array}{l}\text { Moderate degree of } \\
\text { aggregation of } 10- \\
\mathrm{nm} \text { particles }\end{array}$ & $0-1000 \mu \mathrm{g} / \mathrm{mL}$ & $24 \mathrm{~h}$ & MTT assay & $\begin{array}{l}\text { The smaller the } \\
\text { particle size, the } \\
\text { greater the } \\
\text { cytotoxicity. }\end{array}$ \\
\hline $\begin{array}{l}\text { Napierska }{ }^{2} \\
(2009)\end{array}$ & EAHY926 & $\begin{array}{l}\text { L- } 14,15 \mathrm{~nm} \\
\mathrm{~S}-16,19,60 \\
104,335 \mathrm{~nm}\end{array}$ & - & $100 \mu g / m L$ & $24 \mathrm{~h}$ & $\begin{array}{l}\text { MTT assay and } \\
\text { LDH activity } \\
\text { assay }\end{array}$ & $\begin{array}{l}\text { The smaller the } \\
\text { particle size, the } \\
\text { greater the } \\
\text { cytotoxicity. }\end{array}$ \\
\hline Wang $^{61}$ (2009) & HEK293 & $20,50 \mathrm{~nm}$ & - & $0-1000 \mu \mathrm{g} / \mathrm{mL}$ & $24 \mathrm{~h}$ & MTT assay & $\begin{array}{l}\text { Cytotoxicity: } 20 \\
\mathrm{~nm}>50 \mathrm{~nm}\end{array}$ \\
\hline $\begin{array}{l}\text { Morishige }^{79} \\
(2010)\end{array}$ & TPH-I & $\begin{array}{l}30,50,60,300, \\
1000 \mathrm{~nm}\end{array}$ & - & $100 \mu g / \mathrm{mL}$ & $24 \mathrm{~h}$ & $\begin{array}{l}\text { Standard } \\
\text { methylene blue } \\
\text { assay }\end{array}$ & $\begin{array}{l}\text { Cytotoxicity: } 300, \\
1000 \mathrm{~nm}>30,50, \\
70 \mathrm{~nm}\end{array}$ \\
\hline $\mathrm{Ye}^{39}(2010)$ & $\mathrm{H} 9 \mathrm{c} 2(2-\mathrm{I})$ & $\mathrm{S}-2 \mathrm{I}, 48 \mathrm{~nm}$ & - & $0.1-1.6 \mathrm{mg} / \mathrm{mL}$ & $\begin{array}{l}12,24 \\
36.48 \mathrm{~h}\end{array}$ & $\begin{array}{l}\text { LDH activity } \\
\text { assay and MTT } \\
\text { assay }\end{array}$ & $\begin{array}{l}\text { Cytotoxicity: } 21 \\
\mathrm{~nm}>48 \mathrm{~nm}\end{array}$ \\
\hline $\operatorname{Park}^{85}(2010)$ & $\mathrm{HaCaT}$ & $\begin{array}{l}7 \mathrm{~nm} \\
10-20 \mathrm{~nm}\end{array}$ & $\sqrt{ }$ & 0-300 $\mu \mathrm{g} / \mathrm{mL}$ & $48 \mathrm{~h}$ & MTT assay & Not significant \\
\hline $\mathrm{Kim}^{86}(2010)$ & SH-SY5Y & $\begin{array}{l}\text { Lu-15.3, } 16.9 \\
n m\end{array}$ & - & $\begin{array}{l}10,100,1000 \\
\text { ppm }\end{array}$ & $48 \mathrm{~h}$ & MTT assay & Not significant \\
\hline
\end{tabular}

(Continued) 
Table 2 (Continued).

\begin{tabular}{|c|c|c|c|c|c|c|c|}
\hline Source & Cell Type & $\begin{array}{l}\text { Particle } \\
\text { Primary Size }\end{array}$ & $\begin{array}{l}\text { Aggregates/ } \\
\text { Agglomerates }\end{array}$ & Exposure Dose & $\begin{array}{l}\text { Exposure } \\
\text { Time }\end{array}$ & $\begin{array}{l}\text { Assay(s)/ } \\
\text { Method(s) }\end{array}$ & $\begin{array}{l}\text { Size-dependent } \\
\text { Cytotoxicity }\end{array}$ \\
\hline Yuan $^{64}(2010)$ & $\begin{array}{l}\text { PCI2 } \\
\text { HEK293 }\end{array}$ & $\begin{array}{l}\mathrm{S}-20,50, \\
80,140,280, \\
760 \mathrm{~nm}\end{array}$ & - & $20-2000 \mu \mathrm{g} / \mathrm{mL}$ & $24 \mathrm{~h}$ & MTT assay & $\begin{array}{l}\text { Cytotoxicity: } 20 \\
\mathrm{~nm}>50 \mathrm{~nm}>80 \\
\mathrm{~nm}>140,280, \\
760 \mathrm{~nm}\end{array}$ \\
\hline Akhtar $^{72}(2010)$ & A549 & $\mathrm{S}-10,80 \mathrm{~nm}$ & $\sqrt{ }$ & $50-400 \mu \mathrm{g} / \mathrm{mL}$ & $48 \mathrm{~h}$ & $\begin{array}{l}\text { MTT assay and } \\
\text { LDH activity } \\
\text { assay }\end{array}$ & Not significant \\
\hline Yang $^{54}(2010)$ & $\mathrm{HaCaT}$ & $15,30,365 \mathrm{~nm}$ & - & $2.5-80 \mu \mathrm{g} / \mathrm{mL}$ & $24 \mathrm{~h}$ & $\begin{array}{l}\text { CCK-8 assay } \\
\text { and FITC } \\
\text { apoptosis } \\
\text { detection }\end{array}$ & $\begin{array}{l}\text { Cytotoxicity: } 15 \\
\mathrm{~nm}>30 \mathrm{~nm}>365 \\
\mathrm{~nm}\end{array}$ \\
\hline $\mathrm{Ye}^{40}(2010)$ & L-02 & $21,48,86 \mathrm{~nm}$ & - & $200-1000 \mu \mathrm{g} / \mathrm{mL}$ & $\begin{array}{l}12,24,36, \\
48 \mathrm{~h}\end{array}$ & $\begin{array}{l}\text { MTT assay and } \\
\text { LDH activity } \\
\text { assay and } \\
\text { V-FITC/PI } \\
\text { apoptosis } \\
\text { assay }\end{array}$ & $\begin{array}{l}\text { Cytotoxicity: } 21 \\
\mathrm{~nm}>48 \mathrm{~nm}>86 \\
\mathrm{~nm}\end{array}$ \\
\hline $\begin{array}{l}\text { Gonzalez }^{20} \\
(2010)\end{array}$ & A549 & $\begin{array}{l}\text { S-16, 60, } 104 \\
\mathrm{~nm}\end{array}$ & - & $10-500 \mathrm{mg} / \mathrm{mL}$ & $24 \mathrm{~h}$ & MTT assay & $\begin{array}{l}\text { Cytotoxicity: } 16 \\
\mathrm{~nm}>60 \mathrm{~nm}>104 \\
\mathrm{~nm}\end{array}$ \\
\hline Nabeshi $^{56}(2011)$ & $\mathrm{HaCaT}$ & $\begin{array}{l}70,300,1000 \\
n m\end{array}$ & - & $10-1250 \mu \mathrm{g} / \mathrm{mL}$ & $24 \mathrm{~h}$ & $\begin{array}{l}\text { LDH activity } \\
\text { assay }\end{array}$ & $\begin{array}{l}\text { Cytotoxicity: } 70 \\
\mathrm{~nm}>300,1000 \\
\mathrm{~nm}\end{array}$ \\
\hline Nabeshi $^{47}(201 \mathrm{I})$ & RAW264.7 & $\begin{array}{l}70,300,1000 \\
\mathrm{~nm}\end{array}$ & - & $10,30 \mu \mathrm{g} / \mathrm{mL}$ & 5 days & WST-8 assay & $\begin{array}{l}\text { Cytotoxicity: } 70 \\
\mathrm{~nm}>300,1000 \\
\mathrm{~nm}\end{array}$ \\
\hline Ariano $^{65}(2011)$ & GTI-7 & $\mathrm{S}-50,200 \mathrm{~nm}$ & - & I5-292 $\mu \mathrm{g} / \mathrm{mL}$ & $24,72 \mathrm{~h}$ & $\begin{array}{l}\text { Count the cell } \\
\text { number }\end{array}$ & $\begin{array}{l}\text { Cytotoxicity: } 50 \\
\mathrm{~nm}>200 \mathrm{~nm}\end{array}$ \\
\hline Bauer $^{75}(201 \mathrm{I})$ & HUVECs & $\begin{array}{l}\mathrm{S}-16,41,80, \\
212,304 \mathrm{~nm}\end{array}$ & - & $\begin{array}{l}1000,15,000 \\
30,000 \mathrm{NP} / \text { cell }\end{array}$ & $24,48 \mathrm{~h}$ & $\begin{array}{l}\text { MTT assay and } \\
\text { LDH activity } \\
\text { assay }\end{array}$ & $\begin{array}{l}\text { Cytotoxicity: } 304 \\
\mathrm{~nm}>212 \mathrm{~nm}>16, \\
41,80 \mathrm{~nm}\end{array}$ \\
\hline $\mathrm{Lu}^{77}(20 \mathrm{II})$ & $\begin{array}{l}\text { HepG2 } \\
\text { L-02 }\end{array}$ & $7,20,50 \mathrm{~nm}$ & - & $20-640 \mu \mathrm{g} / \mathrm{mL}$ & $48 \mathrm{~h}$ & MTT assay & $\begin{array}{l}\text { Not significant; } \\
\text { cytotoxicity: } 20 \\
\mathrm{~nm}>7 \mathrm{~nm}>50 \\
\mathrm{~nm}\end{array}$ \\
\hline $\mathrm{Li}^{42}(20 \mathrm{II})$ & HepG2 & $\begin{array}{l}19,43,68,498 \\
\mathrm{~nm}\end{array}$ & $\begin{array}{l}\text { Moderate degree of } \\
\text { aggregation of } 19 \mathrm{~nm} \\
\text { particles }\end{array}$ & $12.5-200 \mu \mathrm{g} / \mathrm{mL}$ & $24 \mathrm{~h}$ & $\begin{array}{l}\text { CCK-8 assay } \\
\text { and LDH } \\
\text { activity assay } \\
\text { and annexin } \\
\text { V-FITC/PI } \\
\text { apoptosis } \\
\text { assay }\end{array}$ & $\begin{array}{l}\text { Cytotoxicity: } 19 \\
\mathrm{~nm}>43 \mathrm{~nm}>68 \\
\mathrm{~nm}>498 \mathrm{~nm}\end{array}$ \\
\hline
\end{tabular}

(Continued) 
Table 2 (Continued).

\begin{tabular}{|c|c|c|c|c|c|c|c|}
\hline Source & Cell Type & $\begin{array}{l}\text { Particle } \\
\text { Primary Size }\end{array}$ & $\begin{array}{l}\text { Aggregates/ } \\
\text { Agglomerates }\end{array}$ & Exposure Dose & $\begin{array}{l}\text { Exposure } \\
\text { Time }\end{array}$ & $\begin{array}{l}\text { Assay(s)/ } \\
\text { Method(s) }\end{array}$ & $\begin{array}{l}\text { Size-dependent } \\
\text { Cytotoxicity }\end{array}$ \\
\hline $\begin{array}{l}\text { Corbalan }{ }^{35} \\
(2011)\end{array}$ & HUVECs & $\begin{array}{l}10,50,150,500 \\
\mathrm{~nm}\end{array}$ & - & $\mathrm{I}-100 \mu \mathrm{g} / \mathrm{mL}$ & $\begin{array}{l}3,7,15 \\
30 \mathrm{~h}\end{array}$ & $\begin{array}{l}\text { LDH activity } \\
\text { assay }\end{array}$ & $\begin{array}{l}\text { Cytotoxicity: } 10 \\
\mathrm{~nm}>50 \mathrm{~nm}>150, \\
500 \mathrm{~nm}\end{array}$ \\
\hline Wang $^{63}(2011)$ & $\mathrm{PCl} 2$ & $20,50 \mathrm{~nm}$ & - & $0-300 \mu \mathrm{g} / \mathrm{mL}$ & $\begin{array}{l}12,24,36, \\
48 \mathrm{~h}\end{array}$ & MTT assay & $\begin{array}{l}\text { Cytotoxicity: } 20 \\
\mathrm{~nm}>50 \mathrm{~nm}\end{array}$ \\
\hline Al-Rawi ${ }^{69}(201 \mathrm{I})$ & HeLa & $\begin{array}{l}70,200,500 \\
\mathrm{~nm}\end{array}$ & - & $50 \mu \mathrm{g} / \mathrm{mL}$ & $24 \mathrm{~h}$ & $\begin{array}{l}\text { LDH activity } \\
\text { assay and } \\
\text { WST-I assay }\end{array}$ & $\begin{array}{l}\text { Cytotoxicity: } 70 \\
\mathrm{~nm}>200 \mathrm{~nm}, 500 \\
\mathrm{~nm}\end{array}$ \\
\hline Uboldi $^{82}$ (2012) & Balb/3T3 & $\begin{array}{l}10-25,5-30 \mathrm{~nm} \\
\mathrm{I} 5,35,80,90 \\
\mathrm{~nm}\end{array}$ & $\begin{array}{l}\text { No substantial } \\
\text { aggregation, except } \\
\text { for the } 10-25 \mathrm{~nm} \\
\text { and } 5-30 \mathrm{~nm} \\
\text { particles }\end{array}$ & $\mathrm{I}, 10,100 \mu \mathrm{g} / \mathrm{mL}$ & $72 \mathrm{~h}$ & MTT assay & $\begin{array}{l}\text { Not significant; } \\
\text { Only } 80 \mathrm{~nm} \text { silica } \\
\text { nanoparticles } \\
\text { produced } \\
\text { significant } \\
\text { cytotoxicity. }\end{array}$ \\
\hline Gong $^{55}(2012)$ & $\mathrm{HaCaT}$ & $15,30,100 \mathrm{~nm}$ & - & $0-100 \mu \mathrm{g} / \mathrm{mL}$ & $24 \mathrm{~h}$ & CCK-8 assay & $\begin{array}{l}\text { Cytotoxicity: } 15 \\
\mathrm{~nm}>30 \mathrm{~nm}>100 \\
\mathrm{~nm}\end{array}$ \\
\hline $\begin{array}{l}\text { Napierska }^{26} \\
(2012)\end{array}$ & $\begin{array}{l}\text { A549 } \\
\text { THP-I }\end{array}$ & $\begin{array}{l}\mathrm{S}-2,16,60,104 \\
\mathrm{~nm}\end{array}$ & - & $5 \mu \mathrm{g} / \mathrm{cm}^{2}$ & $24 \mathrm{~h}$ & $\begin{array}{l}\text { LDH activity } \\
\text { assay and MTT } \\
\text { assay }\end{array}$ & $\begin{array}{l}\text { Cytotoxicity: } 2 \\
\mathrm{~nm}>16 \mathrm{~nm}>60 \\
\mathrm{~nm}>104 \mathrm{~nm}\end{array}$ \\
\hline Passagne $^{68}(2012)$ & $\begin{array}{l}\text { HK-2 } \\
\text { LLC-PKI }\end{array}$ & $20,100 \mathrm{~nm}$ & - & $5-500 \mu \mathrm{g} / \mathrm{mL}$ & $24,48,72 \mathrm{~h}$ & WST-I & $\begin{array}{l}\text { Cytotoxicity: } 20 \\
\mathrm{~nm}>100 \mathrm{~nm}\end{array}$ \\
\hline $\mathrm{Kim}^{48}(2012)$ & U937 & $15,50,100 \mathrm{~nm}$ & - & $0-2000 \mu \mathrm{g} / \mathrm{mL}$ & $24 \mathrm{~h}$ & CCK-8 assay & $\begin{array}{l}\text { Cytotoxicity: } 15 \\
\mathrm{~nm}>50 \mathrm{~nm}>100 \\
\mathrm{~nm}\end{array}$ \\
\hline $\begin{array}{l}\text { McCarthy }{ }^{32} \\
(2012)\end{array}$ & Calu-3 & $\begin{array}{l}10,150,500 \\
\mathrm{~nm}\end{array}$ & - & $0-100 \mu \mathrm{g} / \mathrm{mL}$ & $\begin{array}{l}2,6,18 \\
24 \mathrm{~h}\end{array}$ & MTT assay & $\begin{array}{l}\text { Cytotoxicity: } 10 \\
\mathrm{~nm}>150,500 \mathrm{~nm}\end{array}$ \\
\hline $\mathrm{Xu}^{33}(2012)$ & HFL-I & $20,80 \mathrm{~nm}$ & - & $250-2000 \mu \mathrm{g} / \mathrm{mL}$ & $48 \mathrm{~h}$ & MTT assay & $\begin{array}{l}\text { Cytotoxicity: } 20 \\
\mathrm{~nm}>80 \mathrm{~nm}\end{array}$ \\
\hline Gualtieri $^{74}(2012)$ & BEAS-2B & $30,50 \mathrm{~nm}$ & $\sqrt{ }$ & $100 \mu g / m L$ & $20 \mathrm{~h}$ & $\begin{array}{l}\text { LDH activity } \\
\text { assay }\end{array}$ & Not significant \\
\hline Panas $^{27}(2012)$ & $\begin{array}{l}\text { RAW264.7 } \\
\text { A549 }\end{array}$ & $12,25 \mathrm{~nm}$ & $\sqrt{ }$ & $10-200 \mu \mathrm{g} / \mathrm{mL}$ & $24 \mathrm{~h}$ & $\begin{array}{l}\text { LDH activity } \\
\text { assay and } \\
\text { Alamar Blue } \\
\text { assay }\end{array}$ & $\begin{array}{l}\text { Cytotoxicity: } 12 \\
\mathrm{~nm}>25 \mathrm{~nm}\end{array}$ \\
\hline Gazzano $^{80}(2012)$ & $\mathrm{MH}-\mathrm{S}$ & $\begin{array}{l}\text { Pyr-7, } 40 \mathrm{~nm} \\
\text { S- } 1000 \mathrm{~nm}\end{array}$ & $\sqrt{ }$ & $0-160 \mu \mathrm{g} / \mathrm{cm}^{2}$ & $24 \mathrm{~h}$ & $\begin{array}{l}\text { LDH activity } \\
\text { assay }\end{array}$ & $\begin{array}{l}\text { Not significant; } \\
\text { cytotoxicity: } 7,40 \\
\mathrm{~nm}>1000 \mathrm{~nm}\end{array}$ \\
\hline Stępnik ${ }^{81}$ (2012) & $\begin{array}{l}3 T 3-L I \\
W I-38\end{array}$ & Lu-2I, $30 \mathrm{~nm}$ & Partial aggregation & $40-800 \mu \mathrm{g} / \mathrm{mL}$ & $72 \mathrm{~h}$ & $\begin{array}{l}\text { LDH activity } \\
\text { assay and } \\
\text { WST-I assay }\end{array}$ & $\begin{array}{l}\text { Cytotoxicity: } 30 \\
\mathrm{~nm}>21 \mathrm{~nm}\end{array}$ \\
\hline
\end{tabular}

(Continued) 
Table 2 (Continued).

\begin{tabular}{|c|c|c|c|c|c|c|c|}
\hline Source & Cell Type & $\begin{array}{l}\text { Particle } \\
\text { Primary Size }\end{array}$ & $\begin{array}{l}\text { Aggregates/ } \\
\text { Agglomerates }\end{array}$ & Exposure Dose & $\begin{array}{l}\text { Exposure } \\
\text { Time }\end{array}$ & $\begin{array}{l}\text { Assay(s)/ } \\
\text { Method(s) }\end{array}$ & $\begin{array}{l}\text { Size-dependent } \\
\text { Cytotoxicity }\end{array}$ \\
\hline $\begin{array}{l}\text { Napierska }{ }^{38} \\
(20 I 2)\end{array}$ & EA.hy926 & S-16, $60 \mathrm{~nm}$ & - & $25-50 \mu \mathrm{g} / \mathrm{mL}$ & $\begin{array}{l}\text { I, } 2.5,4, \\
24 \mathrm{~h}\end{array}$ & $\begin{array}{l}\text { MTT assay and } \\
\text { LDH activity } \\
\text { assay }\end{array}$ & $\begin{array}{l}\text { Cytotoxicity: } 16 \\
\mathrm{~nm}>60 \mathrm{~nm}\end{array}$ \\
\hline Gehrke $^{44}(20 \mid 3)$ & HT29 & $12,40,200 \mathrm{~nm}$ & $\begin{array}{l}\text { No substantial } \\
\text { aggregation, except } \\
\text { for the } 12 \mathrm{~nm} \\
\text { particles }\end{array}$ & $0.1-500 \mu \mathrm{g} / \mathrm{mL}$ & $24,48,72 \mathrm{~h}$ & $\begin{array}{l}\text { SRB assay and } \\
\text { WST-I assay } \\
\text { and LDH } \\
\text { activity assay }\end{array}$ & $\begin{array}{l}\text { Cytotoxicity: } 12 \\
\mathrm{~nm}>40 \mathrm{~nm}>200 \\
\mathrm{~nm}\end{array}$ \\
\hline Kasper $^{31}$ (2013) & $\begin{array}{l}\text { H44I } \\
\text { ISO-HAS-I }\end{array}$ & $30,70,300 \mathrm{~nm}$ & $\begin{array}{l}\text { Partly agglomerated } \\
\text { of } 30 \mathrm{~nm} \text { particles }\end{array}$ & $6-600 \mu \mathrm{g} / \mathrm{mL}$ & $4 \mathrm{~h}$ & $\begin{array}{l}\text { MTS assay and } \\
\text { LDH activity } \\
\text { assay }\end{array}$ & $\begin{array}{l}\text { Cytotoxicity: } 30 \\
\mathrm{~nm}>70 \mathrm{~nm}>300 \\
\mathrm{~nm}\end{array}$ \\
\hline Freese $^{17}(2014)$ & HUVEC & $30,70 \mathrm{~nm}$ & $\begin{array}{l}\text { The } 30 \mathrm{~nm} \text { particles } \\
\text { tended to } \\
\text { agglomerate with } \\
\text { time }\end{array}$ & $60-150 \mu \mathrm{g} / \mathrm{mL}$ & $24 \mathrm{~h}$ & $\begin{array}{l}\text { MTS assay and } \\
\text { LDH activity } \\
\text { assay }\end{array}$ & $\begin{array}{l}\text { Cytotoxicity: } 70 \\
\mathrm{~nm}>30 \mathrm{~nm}\end{array}$ \\
\hline $\mathrm{Kim}^{66}(2014)$ & U373MG & $20,100 \mathrm{~nm}$ & - & $0-30 \mathrm{mg} / \mathrm{mL}$ & $24 \mathrm{~h}$ & $\begin{array}{l}\text { CellTiter-Glo } \\
\text { luminescent } \\
\text { assay }\end{array}$ & $\begin{array}{l}\text { Cytotoxicity: } 20 \\
\mathrm{~nm}>100 \mathrm{~nm}\end{array}$ \\
\hline Kusaka $^{50}(2014)$ & BMDMs & $\begin{array}{l}30,100,300 \\
1000,3000 \\
10,000 \mathrm{~nm}\end{array}$ & - & $0.03-0.3 \mathrm{mg} / \mathrm{mL}$ & $2 \mathrm{~h}$ & $\begin{array}{l}\text { LDH activity } \\
\text { assay }\end{array}$ & $\begin{array}{l}\text { Cytotoxicity } 30, \\
100,300 \mathrm{~nm}> \\
1000 \mathrm{~nm} \\
>3000,10,000 \mathrm{~nm}\end{array}$ \\
\hline$V_{o}^{70}(20 \mid 4)$ & $\begin{array}{l}\text { RTgill-WI } \\
\text { RTgut-GC } \\
\text { RTL-WI } \\
\text { RTBrain } \\
\text { FHML2-6 } \\
\text { FHMT- } \\
\text { WIGFB3C } \\
\text { GFSk-SI } \\
\text { GloFish } \\
\text { ZEB2J } \\
\text { EelBrain } \\
\text { HEW }\end{array}$ & S-16, $24,44 \mathrm{~nm}$ & - & $1.8-1800 \mu \mathrm{g} / \mathrm{mL}$ & $24 \mathrm{~h}$ & $\begin{array}{l}\text { Alamar Blue } \\
\text { assays }\end{array}$ & $\begin{array}{l}\text { Cytotoxicity: } 16 \\
\mathrm{~nm}>24 \mathrm{~nm}>44 \\
\mathrm{~nm}\end{array}$ \\
\hline Horie $^{73}(2014)$ & $\begin{array}{l}\mathrm{A} 549 \\
\mathrm{HaCaT}\end{array}$ & $\mathrm{S}-7,25,34 \mathrm{~nm}$ & $\sqrt{ }$ & $10-1000 \mu \mathrm{g} / \mathrm{mL}$ & $24,48 \mathrm{~h}$ & $\begin{array}{l}\text { LDH activity } \\
\text { assay and MTT } \\
\text { assay }\end{array}$ & Not significant \\
\hline Mendoza $^{51}(2014)$ & PBMC cells & S- $10,100 \mathrm{~nm}$ & $\begin{array}{l}10 \mathrm{~nm} \text { particles in } \\
\text { culture medium tend } \\
\text { to aggregate }\end{array}$ & 50-4000 ppm & $24,48 \mathrm{~h}$ & $\begin{array}{l}\text { PI staining with } \\
\text { flow } \\
\text { cytometer }\end{array}$ & $\begin{array}{l}\text { Cytotoxicity: } 10 \\
\mathrm{~nm}>100 \mathrm{~nm}\end{array}$ \\
\hline Docter $^{78}(2014)$ & Caco-2 & $20,30,100 \mathrm{~nm}$ & $\sqrt{ }$ & $6-600 \mu \mathrm{g} / \mathrm{mL}$ & $4,24 \mathrm{~h}$ & MTT assay & $\begin{array}{l}\text { Not significant; } 30 \\
\mathrm{~nm} \text { silica particles } \\
\text { produced } \\
\text { significant } \\
\text { cytotoxicity }\end{array}$ \\
\hline
\end{tabular}

(Continued) 
Table 2 (Continued).

\begin{tabular}{|c|c|c|c|c|c|c|c|}
\hline Source & Cell Type & $\begin{array}{l}\text { Particle } \\
\text { Primary Size }\end{array}$ & $\begin{array}{l}\text { Aggregates/ } \\
\text { Agglomerates }\end{array}$ & Exposure Dose & $\begin{array}{l}\text { Exposure } \\
\text { Time }\end{array}$ & $\begin{array}{l}\text { Assay(s)/ } \\
\text { Method(s) }\end{array}$ & $\begin{array}{l}\text { Size-dependent } \\
\text { Cytotoxicity }\end{array}$ \\
\hline $\operatorname{Nemmar}^{36}(2014)$ & HUVEC & $50,500 \mathrm{~nm}$ & - & $0.1-100 \mu \mathrm{g} / \mathrm{mL}$ & $24 \mathrm{~h}$ & $\begin{array}{l}\text { CellTiter-Glo }{ }^{\circledR} \\
\text { Luminescent } \\
\text { Cell Viability } \\
\text { Assay }\end{array}$ & $\begin{array}{l}\text { Cytotoxicity: } 50 \\
\mathrm{~nm}>500 \mathrm{~nm}\end{array}$ \\
\hline Kojima $^{53}(2014)$ & KUP5 & $30,70,300 \mathrm{~nm}$ & $\begin{array}{l}\text { The particles of } \\
\text { SNP70 and SNP300 } \\
\text { appeared to be } \\
\text { loosely aggregated in } \\
\text { DMEM cell culture } \\
\text { medium }\end{array}$ & $\mathrm{I}-30 \mu \mathrm{g} / \mathrm{cm}^{2}$ & $24 \mathrm{~h}$ & WST-I assay & $\begin{array}{l}\text { Cytotoxicity: } 30 \\
\mathrm{~nm}>70 \mathrm{~nm}>300 \\
\mathrm{~nm}\end{array}$ \\
\hline$X_{u e}^{41}(2014)$ & BRL & $\begin{array}{l}20 \mathrm{~nm}, 0.5-6 \\
\mu \mathrm{m}\end{array}$ & $\begin{array}{l}20 \mathrm{~nm} \text { silica } \\
\text { nanoparticle } \\
\text { aggregates were } \\
\text { visible }\end{array}$ & $0.005-1 \mathrm{mg} / \mathrm{mL}$ & $18,24 \mathrm{~h}$ & $\begin{array}{l}\text { Thiazolyl blue } \\
\text { tetrazolium } \\
\text { bromide assay } \\
\text { and LDH } \\
\text { activity assay } \\
\text { and MTT assay }\end{array}$ & $\begin{array}{l}\text { Cytotoxicity: } 20 \\
\mathrm{~nm}>0.5-6 \mu \mathrm{m}\end{array}$ \\
\hline Fede $^{21}(2014)$ & A549 & Lu-9, I8 nm & - & $0.01-0.05 \mathrm{mg} / \mathrm{mL}$ & $2 \mathrm{~h}$ & MTS-assay & $\begin{array}{l}\text { Cytotoxicity: } 9 \\
\mathrm{~nm}>18 \mathrm{~nm}\end{array}$ \\
\hline $\begin{array}{l}\text { Gonzalez }^{22} \\
(2014)\end{array}$ & A549 & $\begin{array}{l}\text { Lys-12, } 40 \mathrm{~nm} \text {, } \\
\mathrm{S}-28,59,139, \\
174 \mathrm{~nm}\end{array}$ & - & $0-1056 \mu \mathrm{g} / \mathrm{mL}$ & $40 \mathrm{~h}$ & $\begin{array}{l}\text { Peak flow } \\
\text { green flow } \\
\text { cytometry- } \\
\text { based } \\
\text { cytotoxicity } \\
\text { measurement }\end{array}$ & $\begin{array}{l}\text { Cytotoxicity } \\
\text { (absence of } \\
\text { serum): L- } 12 \mathrm{~nm} \\
>\text { L-40 nm; S-28 } \\
\mathrm{nm}>\text { S-59 nm } \\
>\text { S- } 139 \mathrm{~nm} \\
>\text { S- } 174 \mathrm{~nm}\end{array}$ \\
\hline $\begin{array}{l}\text { Nagakura }{ }^{57} \\
(2014)\end{array}$ & $\mathrm{HaCaT}$ & $30,70,300 \mathrm{~nm}$ & $\begin{array}{l}30 \mathrm{~nm} \text { particles } \\
\text { approximately } \\
\text { uniformly dispersed } \\
\text { in the medium }\end{array}$ & $0-50 \mu g / \mathrm{cm}^{2}$ & $24 \mathrm{~h}$ & WST-I assay & $\begin{array}{l}\text { Cytotoxicity: } 30 \\
\mathrm{~nm}>70 \mathrm{~nm}>300 \\
\mathrm{~nm}\end{array}$ \\
\hline Tarantini $^{43}(2015)$ & Caco-2 & I5, $55 \mathrm{~nm}$ & $\begin{array}{l}15 \mathrm{~nm} \text { particles } \\
\text { formed aggregates }\end{array}$ & $0-256 \mu \mathrm{g} / \mathrm{mL}$ & $24 \mathrm{~h}$ & XTT assay & $\begin{array}{l}\text { Cytotoxicity: } 15 \\
\mathrm{~nm}>50 \mathrm{~nm}\end{array}$ \\
\hline $\mathrm{Kim}^{83}(2015)$ & $\begin{array}{l}\text { A549 } \\
\text { HepG2 } \\
\text { NIH/3T3 }\end{array}$ & $\begin{array}{l}S-20,40,60,80, \\
100,150,200 \\
n m\end{array}$ & $\sqrt{ }$ & $10-500 \mu \mathrm{g} / \mathrm{mL}$ & $24,72 \mathrm{~h}$ & $\begin{array}{l}\text { LDH activity } \\
\text { assay and MTT } \\
\text { assay }\end{array}$ & Not significant \\
\hline Tokgun $^{23}$ (2015) & A549 & $\begin{array}{l}\mathrm{S}-6,15,30,55 \\
\mathrm{~nm}\end{array}$ & - & $0.1-1000 \mu \mathrm{g} / \mathrm{mL}$ & $72 \mathrm{~h}$ & $\begin{array}{l}\text { CytoToxGlo } \\
\text { kit and TUNEL } \\
\text { analysis }\end{array}$ & $\begin{array}{l}\text { Cytotoxicity: } 6 \\
\mathrm{~nm}>15 \mathrm{~nm}>30, \\
55 \mathrm{~nm}\end{array}$ \\
\hline
\end{tabular}

(Continued) 
Table 2 (Continued).

\begin{tabular}{|c|c|c|c|c|c|c|c|}
\hline Source & Cell Type & $\begin{array}{l}\text { Particle } \\
\text { Primary Size }\end{array}$ & $\begin{array}{l}\text { Aggregates/ } \\
\text { Agglomerates }\end{array}$ & Exposure Dose & $\begin{array}{l}\text { Exposure } \\
\text { Time }\end{array}$ & $\begin{array}{l}\text { Assay(s)/ } \\
\text { Method(s) }\end{array}$ & $\begin{array}{l}\text { Size-dependent } \\
\text { Cytotoxicity }\end{array}$ \\
\hline \multirow[t]{5}{*}{$\begin{array}{l}\text { Guichard }{ }^{34} \\
(2016)\end{array}$} & \multirow[t]{5}{*}{ V79 } & $\begin{array}{l}\text { Pyr 20: } 19 \pm 5 \\
\mathrm{~nm}\end{array}$ & \multirow[t]{5}{*}{$\sqrt{ }$} & \multirow[t]{5}{*}{$1.25-100 \mu \mathrm{g} / \mathrm{cm}^{2}$} & \multirow[t]{5}{*}{$24 \mathrm{~h}$} & \multirow[t]{5}{*}{ WST-I } & \multirow{5}{*}{$\begin{array}{l}\text { Cytotoxicity: } \\
\text { Coll } 15>\mathrm{Pyr} \\
20=\text { Pre } 20>\mathrm{Pyr} \\
25 / 70=\text { Col } 40 / 80 .\end{array}$} \\
\hline & & $\begin{array}{l}\text { Pyr 25/70: } 71 \\
\pm 25 / 25 \pm 8 \mathrm{~nm}\end{array}$ & & & & & \\
\hline & & $\begin{array}{l}\text { Pre } 20: 19 \pm 3 \\
\mathrm{~nm}\end{array}$ & & & & & \\
\hline & & $\begin{array}{l}\text { Col 15: } 15 \pm 4 \\
\mathrm{~nm}\end{array}$ & & & & & \\
\hline & & $\begin{array}{l}\text { Col 40/80: } 79 \\
\pm 3 / 38 \pm 5 \mathrm{~nm}\end{array}$ & & & & & \\
\hline $\mathrm{Li}^{28}(2016)$ & BEAS-2B & $\begin{array}{l}\mathrm{S}-40,60,200 \\
\mathrm{~nm}\end{array}$ & - & $6.25-100 \mu \mathrm{g} / \mathrm{mL}$ & $6,12,24 \mathrm{~h}$ & $\begin{array}{l}\text { MTT assay and } \\
\text { LDH activity } \\
\text { assay }\end{array}$ & $\begin{array}{l}\text { Cytotoxicity: } 40 \\
\mathrm{~nm}>60 \mathrm{~nm}>200 \\
\mathrm{~nm}\end{array}$ \\
\hline Saikia $^{12}(2016)$ & RAW 264.7 & $\mathrm{~S}-50,500 \mathrm{~nm}$ & - & 4-500 $\mu \mathrm{g} / \mathrm{mL}$ & $24 \mathrm{~h}$ & $\begin{array}{l}\text { CCK-8 assay } \\
\text { and LDH } \\
\text { activity assay }\end{array}$ & $\begin{array}{l}\text { Cytotoxicity: } 50 \\
\mathrm{~nm}>500 \mathrm{~nm}\end{array}$ \\
\hline $\begin{array}{l}\text { Manganelli }{ }^{62} \\
(2016)\end{array}$ & HEK293 & $20,50 \mathrm{~nm}$ & - & $25-200 \mu \mathrm{g} / \mathrm{mL}$ & $\begin{array}{l}12,24,36, \\
48 \mathrm{~h}\end{array}$ & MTT assay & $\begin{array}{l}\text { Cytotoxicity: } 20 \\
\mathrm{~nm}>50 \mathrm{~nm}\end{array}$ \\
\hline $\begin{array}{l}\text { Nakanishi }^{52} \\
(2016)\end{array}$ & mBMDCs & $30,70,300 \mathrm{~nm}$ & - & $\mathrm{I}-20 \mu \mathrm{g} / \mathrm{cm}^{2}$ & $24 \mathrm{~h}$ & $\begin{array}{l}\text { LDH activity } \\
\text { assay }\end{array}$ & $\begin{array}{l}\text { Cytotoxicity: } 30 \\
\mathrm{~nm}>70 \mathrm{~nm}>300 \\
\mathrm{~nm}\end{array}$ \\
\hline Gong $^{58}$ (2017) & $\begin{array}{l}\mathrm{HaCaT} \\
\text { HaCaT- } \\
\text { shPARP-I }\end{array}$ & $\mathrm{I} 5 \mathrm{~nm}, \mathrm{I}-5 \mu \mathrm{m}$ & - & $0-200 \mu \mathrm{g} / \mathrm{mL}$ & $24 \mathrm{~h}$ & $\begin{array}{l}\text { CCK-8 assay } \\
\text { and LDH } \\
\text { activity assay } \\
\text { and MTT assay } \\
\text { and flow } \\
\text { cytometric } \\
\text { analysis }\end{array}$ & $\begin{array}{l}\text { Cytotoxicity: } 15 \\
\mathrm{~nm}>\mathrm{I}-5 \mu \mathrm{m}\end{array}$ \\
\hline $\begin{array}{l}\text { Nishijima }{ }^{18} \\
(2017)\end{array}$ & TPH-I & $\begin{array}{l}10,30,50,70 \\
100,300,1000 \\
\mathrm{~nm}\end{array}$ & - & $12.5-200 \mu \mathrm{g} / \mathrm{mL}$ & $6,12,24 \mathrm{~h}$ & $\begin{array}{l}\text { LDH activity } \\
\text { assay }\end{array}$ & Not significant \\
\hline Vicente $^{60}(2017)$ & $\begin{array}{l}\text { KI7 } \\
\text { HDF }\end{array}$ & $\begin{array}{l}\text { Lu- } 20 \mathrm{~nm} \\
70,200,500 \\
\mathrm{~nm}\end{array}$ & $\begin{array}{l}70 \mathrm{~nm} \text { silica } \\
\text { nanoparticle } \\
\text { aggregates were } \\
\text { visible }\end{array}$ & $5-200 \mu \mathrm{g} / \mathrm{mL}$ & $24 \mathrm{~h}$ & $\begin{array}{l}\text { LDH activity } \\
\text { assay and } \\
\text { WST-I assay } \\
\text { and PI staining } \\
\text { and nuclei } \\
\text { counting }\end{array}$ & $\begin{array}{l}\text { Cytotoxicity: } 20 \\
\mathrm{~nm}>70 \mathrm{~nm} \geq 200, \\
500 \mathrm{~nm}\end{array}$ \\
\hline $\begin{array}{l}\text { Premshekharan }{ }^{49} \\
(2017)\end{array}$ & THP-I & $50 \mathrm{~nm}, 2 \mu \mathrm{m}$ & $\begin{array}{l}\text { The particles of } 2 \\
\mu \mathrm{m} \text { appeared to be } \\
\text { loosely aggregated in } \\
\text { cell culture medium }\end{array}$ & $\mathrm{I}-100 \mu \mathrm{g} / \mathrm{mL}$ & $22 \mathrm{~h}$ & MTT assay & $\begin{array}{l}\text { Cytotoxicity: } 50 \\
\mathrm{~nm}>2 \mu \mathrm{m}\end{array}$ \\
\hline
\end{tabular}

(Continued) 
Table 2 (Continued).

\begin{tabular}{|c|c|c|c|c|c|c|c|}
\hline Source & Cell Type & $\begin{array}{l}\text { Particle } \\
\text { Primary Size }\end{array}$ & $\begin{array}{l}\text { Aggregates/ } \\
\text { Agglomerates }\end{array}$ & Exposure Dose & $\begin{array}{l}\text { Exposure } \\
\text { Time }\end{array}$ & $\begin{array}{l}\text { Assay(s)/ } \\
\text { Method(s) }\end{array}$ & $\begin{array}{l}\text { Size-dependent } \\
\text { Cytotoxicity }\end{array}$ \\
\hline $\operatorname{Liu}^{24}$ (2017) & $\begin{array}{l}\text { A549 } \\
\text { A549-shNrf2 } \\
\text { A549-shRNA }\end{array}$ & $\begin{array}{l}\text { I0-20 nm, I-5 } \\
\mu \mathrm{m}\end{array}$ & - & $0-100 \mu \mathrm{g} / \mathrm{mL}$ & $24 \mathrm{~h}$ & $\begin{array}{l}\text { CCK-8 assay } \\
\text { and annexin } \\
\text { V FITC } \\
\text { apoptosis } \\
\text { detection kit }\end{array}$ & $\begin{array}{l}\text { Cytotoxicity: } \\
\text { I0-20 nm >I-5 } \\
\mu \mathrm{m}\end{array}$ \\
\hline Låg $^{30}$ (2018) & $\begin{array}{l}\text { BEAS-2B } \\
\text { HBEC3-KT }\end{array}$ & $10,50 \mathrm{~nm}$ & $\begin{array}{l}10 \mathrm{~nm} \text { particles } \\
\text { showed } \\
\text { polydispersity in } \\
\text { media }\end{array}$ & $0-200 \mu \mathrm{g} / \mathrm{mL}$ & $20 \mathrm{~h}$ & $\begin{array}{l}\text { LDH activity } \\
\text { assay }\end{array}$ & $\begin{array}{l}\text { Cytotoxicity: } 10 \\
\mathrm{~nm}>50 \mathrm{~nm}\end{array}$ \\
\hline Wang $^{15}(2018)$ & HUVECs & $\begin{array}{l}\mathrm{S}-10,25,50, \\
100 \mathrm{~nm}\end{array}$ & $\begin{array}{l}\text { A degree of } \\
\text { aggregation of four } \\
\text { particles }\end{array}$ & $\mathrm{I}-25 \mu \mathrm{g} / \mathrm{mL}$ & $24 \mathrm{~h}$ & $\begin{array}{l}\text { CCK-8 assay } \\
\text { and flow } \\
\text { cytometry } \\
\text { assay }\end{array}$ & $\begin{array}{l}\text { Cytotoxicity: } 10 \\
\mathrm{~nm}>25 \mathrm{~nm}>50 \\
\mathrm{~nm}>100 \mathrm{~nm}\end{array}$ \\
\hline $\begin{array}{l}\text { Fritsch-Decker }{ }^{45} \\
(2019)\end{array}$ & HCTII6 & $\begin{array}{l}12,70,200,500 \\
\mathrm{~nm}\end{array}$ & $\begin{array}{l}\text { I } 2 \mathrm{~nm} \text { NPs were } \\
\text { already aggregated } \\
\text { to } 232 \mathrm{~nm} \text { in } \\
\text { medium without FBS }\end{array}$ & $0-100 \mu \mathrm{g} / \mathrm{mL}$ & $24,48 \mathrm{~h}$ & $\begin{array}{l}\text { LDH activity } \\
\text { assay and } \\
\text { Alamar Blue } \\
\text { assay }\end{array}$ & $\begin{array}{l}\text { Cytotoxicity: } 12 \\
\mathrm{~nm}>70 \mathrm{~nm}>200, \\
500 \mathrm{~nm}\end{array}$ \\
\hline $\mathrm{Kim}^{13}$ (2019) & $\begin{array}{l}\text { HepG2 } \\
\text { A549 } \\
\text { SW480 }\end{array}$ & $\begin{array}{l}\mathrm{S}-20,30,40,50 \\
\mathrm{~nm}\end{array}$ & $\begin{array}{l}\text { Particles aggregates } \\
\text { formed in PBS } \\
\text { solution containing } \\
\text { FBS }\end{array}$ & $5-500 \mu \mathrm{g} / \mathrm{mL}$ & $24 \mathrm{~h}$ & WST-I assay & $\begin{array}{l}\text { Cytotoxicity: } 20, \\
30 \mathrm{~nm}>40,50 \mathrm{~nm}\end{array}$ \\
\hline $\mathrm{Lee}^{16}(2019)$ & HUVECs & $\begin{array}{l}\mathrm{S}-20,30,40,50 \\
\mathrm{~nm}\end{array}$ & - & $5-25 \mu \mathrm{g} / \mathrm{mL}$ & $24 \mathrm{~h}$ & $\begin{array}{l}\text { FITC-annexin } \\
-\mathrm{V} \& \\
\text { propidium } \\
\text { iodide (PI) } \\
\text { assay }\end{array}$ & $\begin{array}{l}\text { Cytotoxicity: } 20 \\
\mathrm{~nm}>30,40,50 \\
\mathrm{~nm}\end{array}$ \\
\hline $\begin{array}{l}\text { Kamikubo }{ }^{3} \\
(2019)\end{array}$ & $\begin{array}{l}\text { Rat } \\
\text { hippocampal } \\
\text { cells } \\
\text { HEK293. }\end{array}$ & $\begin{array}{l}10,30,100 \\
400,1500 \mathrm{~nm}\end{array}$ & - & $0.000 \mathrm{I}-5 \mathrm{mg} / \mathrm{mL}$ & $2 \mathrm{~h}$ & $\begin{array}{l}\text { CTG assay and } \\
\text { MTT assay and } \\
\text { propidium } \\
\text { iodide (PI) } \\
\text { assay }\end{array}$ & $\begin{array}{l}\text { Cytotoxicity: } 10 \\
\mathrm{~nm}>30 \mathrm{~nm}>100 \\
\mathrm{~nm}>400 \mathrm{~nm} \\
>1500 \mathrm{~nm}\end{array}$ \\
\hline $\mathrm{Du}^{67}(2019)$ & $\begin{array}{l}\text { N9 } \\
\text { bEnd.3 } \\
\text { HT22 }\end{array}$ & $\begin{array}{l}\mathrm{S}-50,100,300 \\
\mathrm{~nm}\end{array}$ & - & $25-200 \mu \mathrm{g} / \mathrm{mL}$ & $24 \mathrm{~h}$ & MTS assay & $\begin{array}{l}\text { Cytotoxicity in } \\
\text { N9 cells: } 50 \mathrm{~nm} \\
>100 \mathrm{~nm}>300 \mathrm{~nm}\end{array}$ \\
\hline $\mathrm{Li}^{29}$ (2019) & BEAS-2B & $\begin{array}{l}\mathrm{S}-40,60,200 \\
\mathrm{~nm}\end{array}$ & - & $25 \mu \mathrm{g} / \mathrm{mL}$ & $24 \mathrm{~h}$ & CCK-8 assay & $\begin{array}{l}\text { Cytotoxicity: } 40 \\
n m>60 n m>200 \\
n m\end{array}$ \\
\hline Leibe $^{10}(2019)$ & $\begin{array}{l}\text { RAW } 264.7 \\
\text { A549 }\end{array}$ & $12,50 \mathrm{~nm}$ & $\begin{array}{l}\text { Large numbers of } 50 \\
\mathrm{~nm} \text { particles } \\
\text { agglomerates in the } \\
\text { absence of serum }\end{array}$ & $10-100 \mu \mathrm{g} / \mathrm{mL}$ & $24 \mathrm{~h}$ & $\begin{array}{l}\text { LDH activity } \\
\text { assay and } \\
\text { Alamar Blue } \\
\text { assay }\end{array}$ & $\begin{array}{l}\text { Cytotoxicity: } 12 \\
\mathrm{~nm}>50 \mathrm{~nm}\end{array}$ \\
\hline Wang $^{76}(2020)$ & HUVECs & $20,100 \mathrm{~nm}$ & - & $0-200 \mu \mathrm{g} / \mathrm{mL}$ & $24 \mathrm{~h}$ & $\begin{array}{l}\text { CCK-8 assay } \\
\text { and LDH } \\
\text { activity assays }\end{array}$ & $\begin{array}{l}\text { Cytotoxicity: } 100 \\
\mathrm{~nm}>20 \mathrm{~nm}\end{array}$ \\
\hline
\end{tabular}




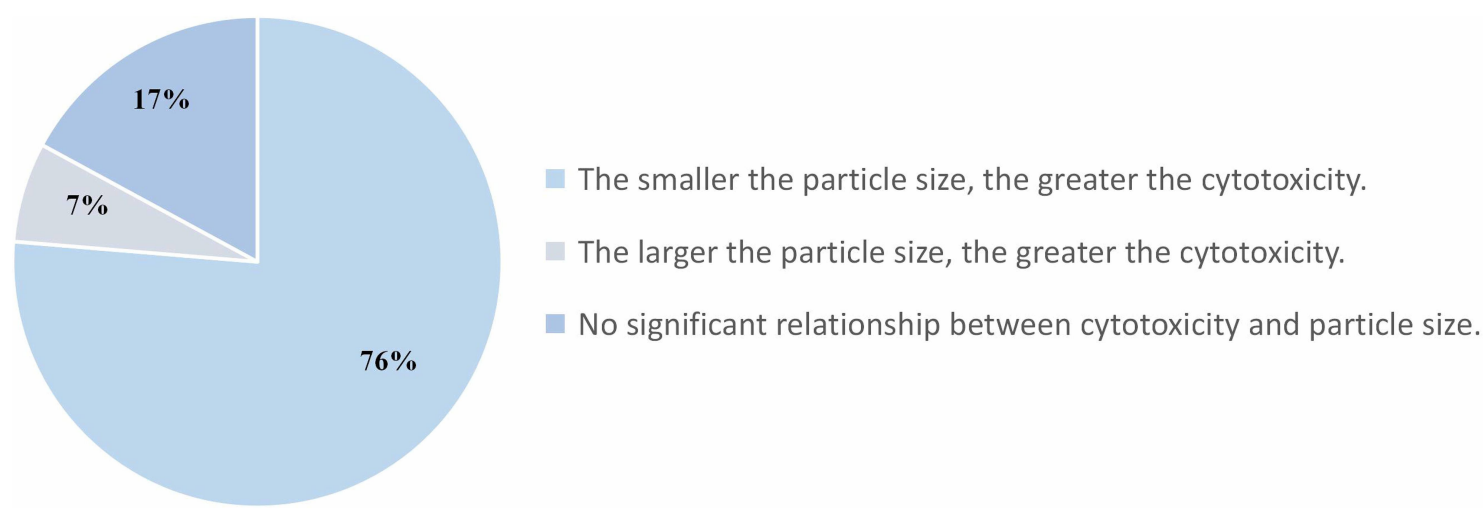

Figure 2 Fan-shaped diagram of the relationship between cytotoxicity of aSiNPs and its particle size.

Napierska et $\mathrm{al}^{2}$ reported that exposures to aSiNPs (14-335 nm) would result in cytotoxic damage and a decrease in cell survival in human umbilical vein endothelial cell line (EAHY926) in a dose-related manner. Concentrations leading to a $50 \%$ reduction in cell viability $\left(\mathrm{TC}_{50}\right)$ declined gradually with the nanoparticle size decreased. Furthermore, the smaller particles also appeared to affect the exposed cells faster within just a few hours. The cytotoxicity of a series of aSiNPs $(2-335 \mathrm{~nm})$ in EAHY926 cell line and J774 differentiated monocyte-macrophage mouse cell line was investigated using MTT and WST1 assays, respectively. When cells were exposed to the same mass of aSiNPs, larger particles were less toxic compared to smaller ones. ${ }^{37}$ Napierska et $\mathrm{al}^{38}$ studied the cytotoxicity response of EAHY926 cells to aSiNPs of two sizes (16 and $60 \mathrm{~nm}$ ). Results of MTT and LDH assays showed that cytotoxic effects could be detected after four hours exposure to $16 \mathrm{~nm}$ aSiNPs at the concentration of $50 \mu \mathrm{g} / \mathrm{mL}$. However, no significant cytotoxicity was found for $60 \mathrm{~nm}$ aSiNPs at any dose and any time of exposure. Ye et $\mathrm{al}^{39}$ exposed rat embryonic ventricular myocardial cell line H9c2 (2-1) to 21 and 48 $\mathrm{nm}$ aSiNPs, and assessed cell viability, oxidative stress and cell cycle arrest. Consequently, both aSiNPs produced significant decreases in viabilities in dose-dependent manners. Furthermore, silica nanoparticles of smaller size possessed higher cytotoxicity.

\section{Size-dependent Cytotoxicity of aSiNPs on Cell Lines from Digestive System}

In the study of Ye et al, ${ }^{40}$ the normal human hepatic cell line (L-02) was exposed to $0.2,0.4$, and $0.6 \mathrm{mg} / \mathrm{mL}$ of aSiNPs $(21,48$, and $86 \mathrm{~nm}$ ) for $12,24,36$, and $48 \mathrm{~h}$. As indicated by MTT and LDH assays, $21 \mathrm{~nm}$ aSiNPs showed significantly higher cytotoxicity than the large sizes of aSiNPs. Xue et $\mathrm{al}^{41}$ exposed buffalo rat liver (BRL) cell line to nano- and microsized silica particles $(20 \mathrm{~nm}$ and $0.5-6 \mu \mathrm{m})$. Both particles exhibited significant toxicity as determined by MTT, LDH leakage and mitochondrial membrane potential assessments. Moreover, greater effects were found for the silica nanoparticle samples than for the micrometer particle samples. $\mathrm{Li}$ et $\mathrm{al}^{42}$ compared the potential toxicity induced by aSiNPs with different sizes $(19,43,68$, and $498 \mathrm{~nm})$ on cultured human hepatoma cell line (HepG2). Results of CCK-8 and LDH release assay suggested that the cytotoxicity of aSiNPs strongly depended on the particle size, and smaller particles possessed higher toxic effects. Kim et $\mathrm{al}^{13}$ studied the cytotoxicity of different sizes of aSiNPs $(20,30,40$, and 50 $\mathrm{nm})$ in HepG2 cells and two other human carcinoma cell lines (A549 and SW480). The result of cell viability manifested that aSiNPs smaller than $30 \mathrm{~nm}$ in size were lethal to the cells, while the cytotoxicity of 40 and $50 \mathrm{~nm}$ aSiNPs was slight.

Tarantini et $\mathrm{al}^{43}$ introduced human intestinal cell line (Caco-2), which is a well characterized model of the intestinal epithelium and commonly used in toxicity studies. Following exposures to aSiNPs (15 and $55 \mathrm{~nm}$ ), a statistically significant dose-dependent decrease in cell viability was observed in the $15 \mathrm{~nm}$ aSiNPs treated group, in contrast, $55 \mathrm{~nm}$ aSiNPs only affected viability of Caco2 cells at the highest tested dose. Gehrke et $\mathrm{al}^{44}$ assessed the toxic effects of $12 \mathrm{~nm}, 40 \mathrm{~nm}$, and $200 \mathrm{~nm}$ aSiNPs in human colon carcinoma cell line (HT29). Size-dependent cytotoxicity was confirmed using the SRB assay, WST-1 assay and LDH activity assay. Fritsch-Decker et $\mathrm{a}^{45}$ tested the effects of aSiNPs with nominal diameters of 70, 200, and $500 \mathrm{~nm}$ on the viability of human colon cancer 
epithelial cell line (HCT116). Administration of particles with increasing diameters but at the same mass concentration (10 or $50 \mu \mathrm{g} / \mathrm{mL}$ ) resulted in an inverse relationship of particle size and cytotoxicity, larger particles were less toxic compared to smaller particles.

\section{Size-dependent Cytotoxicity of aSiNPs on Cell Lines} from Monocyte Macrophage System

Waters et $\mathrm{al}^{46}$ exposed RAW 264.7 cells to aSiNPs (7-500 $\mathrm{nm})$ with mass concentrations from 0 to $1000 \mu \mathrm{g} / \mathrm{mL}$, and observed the dose-response and size-dependent relationship for cytotoxicity. In addition, whole genome microarray analysis of the early gene expression changes induced by 10 and $500 \mathrm{~nm}$ aSiNPs manifested that the magnitude of changes for the majority of affected genes correlated more tightly with particle surface area than either particle mass or number. In other words, it was also identified that the changes of gene expression were particle size specific. Nabeshi et $\mathrm{al}^{47}$ investigated the cytotoxicity of 70,300 , and $1000 \mathrm{~nm}$ aSiNPs in RAW264.7 cells using WST-8 cell proliferation assay. As shown, $30 \mu \mathrm{g} / \mathrm{mL}$ of 300 and 1000 $\mathrm{nm}$ aSiNPs treatment for five days did not induce any toxic effect, while $70 \mathrm{~nm}$ aSiNPs treatment induced obvious cytotoxicity. Saikia et al ${ }^{12}$ exposed RAW 264.7 cells to $50 \mathrm{~nm}$ and $500 \mathrm{~nm}$ aSiNPs, and measured the $\mathrm{LC}_{50}$ values of each aSiNPs in the presence and absence of proteins. Results manifested that with the decrease of particle size, the cytotoxicity of aSiNPs increased by an increase in the surface area. Furthermore, the presence of the protein corona reduced the toxicity of both aSiNPs, which was probably due to the reduction of particle uptake efficiency.

Kim et $\mathrm{al}^{48}$ assessed the cytotoxicity of aSiNPs $(15,50$, $100 \mathrm{~nm}$ ) on human macrophage cells (U937) by the CCK8 assay. As shown, the cell viability decreased depending on the particles size, and $15 \mathrm{~nm}$ particles triggered cell death more significantly than did $50 \mathrm{~nm}$ or $100 \mathrm{~nm}$ particles. The $\mathrm{LD}_{50}$ of $15 \mathrm{~nm}$ aSiNPs was $1.29 \mathrm{mg} / \mathrm{mL}$ and that of $50 \mathrm{~nm}$ aSiNPs was $1.5 \mathrm{mg} / \mathrm{mL}$. In the study conducted by Premshekharan et al, ${ }^{49}$ the MTT assay was performed to explore the non-cytotoxic exposure levels of engineered $50 \mathrm{~nm}$ and $2 \mu \mathrm{m}$ aSiNPs on differentiated THP-1 macrophages. For $2 \mu \mathrm{m}$ silica particles, dosage of $50 \mu \mathrm{g} / \mathrm{mL}$ and below did not differ apparently from the control, whereas for $50 \mathrm{~nm}$ aSiNPs, doses of $10 \mu \mathrm{g} / \mathrm{mL}$ and below did not differ significantly from the control. Thus, $50 \mathrm{~nm}$ aSiNPs was more toxic than $2 \mu \mathrm{m}$ particles. Kusaka et $\mathrm{al}^{50}$ addressed the relationship between the size of aSiNPs $(30-10,000 \mathrm{~nm})$ and the cytotoxicity as well as inflammatory activity in primary mouse macrophages (C57BL/6N mouse bone marrow-derived macrophages, BMDMs). The size-dependent induction of cytotoxicity and IL-1 $\beta$ secretion was observed, the toxic activity of 30-1000 nm aSiNPs was apparently higher than that of $3000 \mathrm{~nm}$ and 10,000 $\mathrm{nm}$ silica particles.

In the research of Mendoza et al, ${ }^{51}$ the effects of 10 or $100 \mathrm{~nm}$ aSiNPs on human peripheral blood mononuclear cells (PBMC) were examined. Ten nanometers of aSiNPs were more cytotoxic and induced more oxidative damage than $100 \mathrm{~nm}$ particles. Nakanishi et $\mathrm{al}^{52}$ examined LDH release as well as IL-1 $\beta$ and IL-18 production after incubating mouse bone marrow dendritic cells (mBMDCs) with aSiNPs of different sizes (30, 70, and $300 \mathrm{~nm})$. An obviously size-dependent toxic and inflammation induction effect was confirmed, in which the greatest cytotoxicity was seen with $30 \mathrm{~nm}$ aSiNPs. Kojima et $\mathrm{al}^{53}$ further investigated the mechanism of inflammatory response in mouse Kupffer cell line (KUP5) induced by aSiNPs of 30, 70 , and $300 \mathrm{~nm}$. The cell viability decreased apparently with the particle size. In addition, $30 \mathrm{~nm}$ aSiNPs led to the greatest increase of IL- $1 \beta$ secretion, while the effect of $70 \mathrm{~nm}$ aSiNPs was similar to that of $300 \mathrm{~nm}$ particles.

\section{Size-dependent Cytotoxicity of aSiNPs on Cell Lines from Epidermis}

Yang et $\mathrm{al}^{54}$ evaluated the effects of aSiNPs $(15,30$, and $365 \mathrm{~nm}$ ) on cell viability, cell cycle and apoptosis in human epidermal keratinocyte cell line (HaCaT). The $\mathrm{IC}_{50}$ values of $15 \mathrm{~nm}, 30 \mathrm{~nm}$ and microsized silica particles were $23.0 \mu \mathrm{g} / \mathrm{mL}, 27.3 \mu \mathrm{g} / \mathrm{mL}$ and $34.8 \mu \mathrm{g} / \mathrm{mL}$, respectively. Furthermore, the smaller $\mathrm{SiO}_{2}$ particle size was, the higher apoptotic rate the cells underwent. Gong et $\mathrm{al}^{55}$ explored the adverse effects of aSiNPs $(15,30$, and $100 \mathrm{~nm}$ ) on HaCaT cells as well. As observed in CCK-8 assay, exposure to aSiNPs decreased the cell viability in a concentration- and size-dependent manner, and the $\mathrm{IC}_{50}$ values of $24 \mathrm{~h}$ exposure were $19.4 \pm 1.3,27.7 \pm 1.5$ and 35.9 $\pm 1.6 \mu \mathrm{g} / \mathrm{mL}$ for 15,30 , and $100 \mathrm{~nm}$ aSiNPs, respectively. The tendency of smaller nanoparticles showing higher toxicity was found. The nanoscale silica particles used by the two research groups were both 15 and $30 \mathrm{~nm}$, and the $\mathrm{IC}_{50}$ values of each size of nanosilica were similar.

Nabeshi et $\mathrm{al}^{56}$ illustrated the size-dependent cytotoxicity of aSiNPs $(70,300$, and $1000 \mathrm{~nm})$ on HaCaT cells. Results of LDH release, intracellular ROS level and DNA oxidative damage indicated that the smallest particles produced greatest toxic effects. Then, they further studied the 
cytotoxic effects and inflammatory response caused by 30 , 70, and $300 \mathrm{~nm}$ aSiNPs, and a clearly size-dependent manner of aSiNPs could be also concluded in cell viability and IL-6 production. ${ }^{57}$ Gong et al $^{58}$ reported that exposure of $\mathrm{HaCaT}$ cells and HaCaT-shPARP-1 cells to $15 \mathrm{~nm}$ aSiNPs resulted in significantly decreased cell viability in a dose-dependent manner. Meanwhile, flow cytometric analysis showed the apoptotic rate in HaCaT-shPARP-1 cells induced by nanosized $\mathrm{SiO}_{2}(15 \mathrm{~nm})$ was significantly higher than by microsized $\mathrm{SiO}_{2}(1-5 \mu \mathrm{m})$.

In the study of $\mathrm{Yu}$ et $\mathrm{al},{ }^{59}$ mouse keratinocytes cells (HEL-30) were exposed for $24 \mathrm{~h}$ to various concentrations $(0-200 \mu \mathrm{g} / \mathrm{mL})$ of aSiNPs with different sizes $(30,48,118$, and $535 \mathrm{~nm}$ ). Results of LDH and MTT assay showed dose- and size-dependent cytotoxicity of 30 and $48 \mathrm{~nm}$ nanoparticles, while larger sizes of aSiNPs (118 and 535 $\mathrm{nm}$ ) exhibited less toxicity compared with smaller nanoparticles. Vicente et $\mathrm{al}^{60}$ investigated the toxicological profile of aSiNPs $(20,70,200$, and $500 \mathrm{~nm})$ in human keratinocytes (K17) and human dermal fibroblasts (HDF), and described that the ultra-small particles $(20 \mathrm{~nm})$ was the most toxic aSiNPs, whereas particles larger than $70 \mathrm{~nm}$ demonstrated to be nontoxic for both dermal cells in a wide range of concentrations.

\section{Size-dependent Cytotoxicity of aSiNPs on Cell Lines from Kidney or Nervous System}

Wang et $\mathrm{al}^{61,62}$ showed that exposure to 20 or $50 \mathrm{~nm}$ aSiNPs at dosage levels between 20 and $100 \mu \mathrm{g} / \mathrm{mL}$ decreased cell viability of cultured human embryonic kidney cells (HEK293) in a dose-dependent manner. Median lethal dose $\left(\mathrm{LD}_{50}\right)$ of $24 \mathrm{~h}$ exposure was $80.2 \pm 6.4$ and $140.3 \pm 8.6 \mu \mathrm{g} / \mathrm{mL}$ for 20 and $50 \mathrm{~nm}$ aSiNPs, respectively. The same research group evaluated the neurotoxicity of these aSiNPs in pheochromocytoma cells (PC12) as well. As determined by MTT assay, the cell viability decreased as the function of both dose and time. The $\mathrm{LD}_{50}$ values obtained after $24 \mathrm{~h}$ exposure were $120 \pm 8 \mu \mathrm{g} / \mathrm{mL}$ for the 20 $\mathrm{nm}$ aSiNPs and $320 \pm 10 \mu \mathrm{g} / \mathrm{mL}$ for the $50 \mathrm{~nm}$ aSiNPs. ${ }^{63}$ Yuan et $\mathrm{al}^{64}$ studied the toxic effects of six sizes aSiNPs $(20,50,80,140,280$, and $760 \mathrm{~nm})$ also using HEK293 cells and $\mathrm{PC} 12$ cells. Compared with microsized- $\mathrm{SiO}_{2}$ $(140,280$, and $800 \mathrm{~nm})$, nanosized-SiO ${ }_{2}(20,50$, and 80 $\mathrm{nm}$ ) caused more severe cell damage, and it was obvious that the $\mathrm{IC}_{50}$ values of aSiNPs increased with the particle size. Kamikubo et $\mathrm{al}^{3}$ investigated the toxic effects of aSiNPs $(10,30,100,400,1500 \mathrm{~nm})$ on primary cultured rat hippocampal cells and HEK29 cells. As determined by the CellTiter-Glo 2.0 (CTG) Luminescent Cell Viability Assay system, aSiNPs with smaller sizes tended to cause higher toxicity on both types of cells at concentrations of 0.03-1 $\mathrm{mg} / \mathrm{mL}$. In addition, compared to HEK293 cells, rat hippocampal cells were more vulnerable to aSiNPs.

In the study of Ariano et al, ${ }^{65}$ the responses of the well differentiated neuronal cell line (GT1-7) to 50 and $200 \mathrm{~nm}$ aSiNPs were compared. The $50 \mathrm{~nm}$ aSiNPs affected cell proliferation in a dose-dependent way. In contrast, $200 \mathrm{~nm}$ aSiNPs did not show any toxicity even at relatively high concentrations. Kim et $\mathrm{al}^{66}$ determined the cytotoxicity of aSiNPs with mean sizes of either $20 \mathrm{~nm}$ or $100 \mathrm{~nm}$ in human glioblastoma cell line (U373MG). The results indicated that the $20 \mathrm{~nm}$ nanoparticles were more toxic than the $100 \mathrm{~nm}$ nanoparticles. Du et $\mathrm{al}^{67}$ compared the neurotoxicity of commercial 50, 100, and $300 \mathrm{~nm}$ Stöber aSiNPs using bEnd.3, N9 and HT22 cells. The result of MTS assay indicated that three aSiNPs induced size- and dosedependent cytotoxicity in N9 cells, with smaller particles inducing higher cytotoxicity. In contrast, no alteration of cell viability was detected in bEnd. 3 and HT22 cells. Passagne et $\mathrm{al}^{68}$ reported on the cytotoxicity of $20 \mathrm{~nm}$ and $100 \mathrm{~nm}$ aSiNPs in two renal proximal tubular cell lines (human HK-2 and porcine LLC-PK1). Results of a WST-1 assay indicated that both aSiNPs reduced cell viability in a dose- and time-dependent manner, and $20 \mathrm{~nm}$ aSiNPs was more cytotoxic than $100 \mathrm{~nm}$ aSiNPs.

\section{Size-dependent Cytotoxicity of aSiNPs on Other Kinds of Cell Lines}

Al-Rawi et $\mathrm{al}^{69}$ evaluated the possible size-dependent toxicity of aSiNPs $(70,200$, and $500 \mathrm{~nm})$ in human cervical carcinoma cell line (HeLa). In the presence of serum, all three sizes of aSiNPs did not show any negative effect on the viability of HeLa cells. However, compared to 200 $\mathrm{nm}$ and $500 \mathrm{~nm}$ aSiNPs, $70 \mathrm{~nm}$ aSiNPs diminished the cell viability apparently when the serum was absent. In the study of Vo et al, ${ }^{70}$ twelve adherent fish cell lines (RTgillW1, RTgut-GC, RTL-W1, RTBrain, FHML2-6, FHMTW1, GFB3C, GFSk-S1, GloFish, ZEB2J, EelBrain, and HEW) derived from six species (rainbow trout, fathead minnow, zebrafish, goldfish, haddock, and American eel) were used to investigate the toxic effects of aSiNPs (16, 24 , and $44 \mathrm{~nm}$ ). Toxicity produced by aSiNPs appeared to be size-, time-, temperature-, and dose-dependent as well as tissue-specific. Smaller particles $(16 \mathrm{~nm})$ were relatively more toxic than larger sized ones (24 and $44 \mathrm{~nm}$ ). 
Size-independent Cytotoxicity of aSiNPs Size-independent Cytotoxicity of aSiNPs on Cell Lines from Respiratory System

Lin et $\mathrm{al}^{71}$ found that $15 \mathrm{~nm}$ or $46 \mathrm{~nm}$ aSiNPs could reduce A549 cell viability in a dose-dependent manner. Nevertheless, the cytotoxicity of $15 \mathrm{~nm}$ and $46 \mathrm{~nm}$ aSiNPs were not significantly different, since the similar hydrodynamic sizes of these two nanoparticles. Akhtar et $\mathrm{al}^{72}$ performed MTT assay and LDH activity assays to explore the viability of A549 cells exposed to two sizes $(10$ and $80 \mathrm{~nm})$ of aSiNPs. Due to the agglomeration of particles in cell culture medium, the toxicity did not differ significantly between this two aSiNPs. In the study of Horie et al, ${ }^{73} \operatorname{aSiNPs}(7,25$, and $34 \mathrm{~nm}$ ) were dispersed directly in DMEM-FBS at concentrations of 10 , 100 , and $1000 \mu \mathrm{g} / \mathrm{mL}$. There was no significant difference in the changes in mitochondrial activity of A549 and $\mathrm{HaCaT}$ cells induced by different sizes of particles. The authors found that the aSiNPs formed large secondary particles and accumulated onto cells by gravity sedimentation, therefore, the concentrations of the nanoparticles in dispersion did not correctly reflect the concentration to which the cells were exposed. In the research of Gualtieri et al, ${ }^{74} 30$ and $50 \mathrm{~nm}$ aSiNPs were examined for their cytotoxicity in BEAS-2B cells. However, little toxicity of both aSiNPs was generally observed, due to the formation of micrometer-sized agglomerates in the absence of bovine serum albumin in the culture medium.

\section{Size-independent Cytotoxicity of aSiNPs on Cell Lines from Cardiovascular System}

Bauer et $\mathrm{al}^{75}$ exposed HUVECs to aSiNPs with diameters ranging from $16 \mathrm{~nm}$ to $304 \mathrm{~nm}$. As assessed by the MTT reduction method, mitochondrial activity significantly decreased upon incubation of aSiNPs with diameters between $212 \mathrm{~nm}$ and $304 \mathrm{~nm}$. In contrast, aSiNPs with a diameter of $80 \mathrm{~nm}$ or less showed no cytotoxicity within the same particle concentrations. The authors observed that larger sized silica particles accumulated around the nucleus and blocked the cell migration obviously, but the reason why smaller sized silica nanoparticles did not show obvious toxicity was not clearly stated. Freese et al ${ }^{17}$ investigated the cytotoxicity of aSiNPs ( 30 and $70 \mathrm{~nm}$ ) in HUVECs. As measured by the MTS-assay and LDH activity assay, the cell viability of HUVECs treated with $70 \mathrm{~nm}$ particles under stretch conditions was significantly decreased up to $77 \%$ $( \pm 12 \%)$. By comparison, $30 \mathrm{~nm}$ particles did not decrease the cell viability, owing to the tendency of agglomeration over time. Wang et $\mathrm{al}^{76}$ demonstrated that both $20 \mathrm{~nm}$ and $100 \mathrm{~nm}$ aSiNPs decreased the cell viability of HUVECs in a concentration-dependent manner from the minimal toxic concentration $(50 \mu \mathrm{g} / \mathrm{mL})$, whereas $100 \mathrm{~nm}$ aSiNPs was found to be more toxic than $20 \mathrm{~nm}$ aSiNPs. An in vitro sedimentation, diffusion and dosimetry (ISDD) model was introduced to estimate the aSiNPs sedimentations onto the cell surface, and results suggested that $100 \mathrm{~nm}$ aSiNPs reached to the cell surface more efficiently than $20 \mathrm{~nm}$ aSiNPs over time, larger aSiNPs thus have a higher effective exposure concentration than smaller particles.

\section{Size-independent Cytotoxicity of aSiNPs on Cell Lines from Digestive System}

The adverse effects of 7-50 nm aSiNPs on HepG2 cells was studied by $\mathrm{Lu}$ et al, ${ }^{77}$ whose results showed that the toxicity of $20 \mathrm{~nm}$ aSiNPs was much higher than that of 7 $\mathrm{nm}$ aSiNPs, while $50 \mathrm{~nm}$ aSiNPs did not have a significant cytotoxic effect at any concentration. In further comparison, it was found that $20 \mathrm{~nm}$ aSiNPs produced stronger oxidative damage than $7 \mathrm{~nm}$ aSiNPs. Docter et $\mathrm{al}^{78}$ reported that compared with untreated control Caco-2 cells, exposure to $30 \mathrm{~nm}$ aSiNPs reduced the cell vitality significantly. In contrast, low toxicity was observed upon treatment with $20 \mathrm{~nm}$ or $100 \mathrm{~nm}$ aSiNPs. The authors implied that the adverse effects triggered by $30 \mathrm{~nm}$ aSiNPs were significantly ameliorated upon formation of the protein corona, which they found was efficiently established on all aSiNPs studied. As a potential explanation, corona formation reduced cellular uptake of $30 \mathrm{~nm}$ aSiNPs, which was, however, not significantly affected by particle surface charge in their model.

\section{Size-independent Cytotoxicity of aSiNPs on Cell Lines from Monocyte Macrophage System}

Morishige et al ${ }^{79}$ evaluated the cytotoxicity of differentsized silica particles $(30-1000 \mathrm{~nm})$ on THP-1 cells. Silica particles with diameter of 300 and $1000 \mathrm{~nm}$ showed strong cytotoxicity which was depended on ROS level, whereas 30, 50, and $70 \mathrm{~nm}$ aSiNPs did not induce cell death obviously. Nishijima et $\mathrm{al}^{18}$ examined the effects of aSiNPs in THP-1 cells with a large overall size range $(10,30,50,70,100,300$, and $1000 \mathrm{~nm})$. The cytotoxicity in the dose range from 12.5 to $200 \mu \mathrm{g} / \mathrm{mL}$ at six and twelve hours was hardly detected. Meanwhile, dose-dependent cytotoxicity was observed in all treated groups at $24 \mathrm{~h}$, at a dose greater than $100 \mu \mathrm{g} / \mathrm{mL}$, while the effect of particle size on the toxicity was not significant. Further assessment of inflammatory cytokines showed there was a bell-shaped size-specific effect, where the silica particles with a diameter of $50 \mathrm{~nm}$ induced the greatest secretion of IL- 
$1 \beta$ and TNF- $\alpha$ and silica particles with smaller or larger diameters had progressively less effect (overall size range, $10-1000 \mathrm{~nm})$. Gazzano et $\mathrm{al}^{80}$ reported the toxicity of aSiNPs with different sizes (7, 40, and $1000 \mathrm{~nm}$ ) on murine alveolar macrophages (MH-S). As manifested, except for $1000 \mathrm{~nm}$ silica particles, an increase in cytotoxic activity was shown on the other two samples. However, cytotoxic damage observed of 7 and $40 \mathrm{~nm}$ aSiNPs was similar, since the aggregation of $7 \mathrm{~nm}$ aSiNPs.

\section{Size-independent Cytotoxicity of aSiNPs on Other Kinds of Cell Lines}

Stępnik et $\mathrm{al}^{81}$ reported the potential toxic effects in murine (3T3-L1) and human (WI-38) fibroblast cell lines of commercially available aSiNPs. Results indicated that 3T3-L1 cells were more sensitive to aSiNPs than WI-38 cells, and $21 \mathrm{~nm}$ aSiNPs induced no, or marginal, cytotoxicity on WI-38 cells, whereas $30 \mathrm{~nm}$ aSiNPs was found to be cytotoxic at the higher concentrations. This could be the result due to the larger hydrodynamic diameter of $21 \mathrm{~nm}$ aSiNPs, as measured by dynamic light scattering (DLS), the hydrodynamic sizes of 21 $\mathrm{nm}$ and $30 \mathrm{~nm}$ aSiNPs in distilled water were $66 \pm 3 \mathrm{~nm}$ and 41 $\pm 1 \mathrm{~nm}$, respectively. Uboldi et al ${ }^{82}$ examined the cytotoxicity induced by $1-100 \mu \mathrm{g} / \mathrm{mL}$ of aSiNPs with a size diameter ranging from $16 \mathrm{~nm}$ to $300 \mathrm{~nm}$, and showed that the viability of Balb/3T3 mouse fibroblasts was slightly impaired only after exposing to $80 \mathrm{~nm}$ aSiNPs. The authors implied that the absence of toxicity might be due to the huge aggregate formation of aSiNPs and the sensitivity of the cell line studied. Kim et $\mathrm{al}^{83}$ cultivated three types of cells, mouse embryonic fibroblasts (NIH/3T3), A549, and HepG2, with exposure of seven sizes aSiNPs (20, 40, 60, 80, 100, 150, $200 \mathrm{~nm})$. The NIH/3T3 cells showed dose-dependent reduction in viability, and larger sized particles caused higher cytotoxicity. The following intracellular ROS measurement indicated that 100 and $200 \mathrm{~nm}$ aSiNPs induced the production of more ROS than 20 or 60 nm aSiNPs. For both the A549 and the HepG2 cells, there was no significant difference in viability reduction between different doses $(\geq 50 \mu \mathrm{g} / \mathrm{mL})$ and sizes except for $60 \mathrm{~nm}$ aSiNPs, owing to the preferential endocytosis of this nanoparticle observed. Park et $\mathrm{al}^{84}$ verified the developmental toxicity of four well-characterized aSiNPs $(10,30,80$, and $400 \mathrm{~nm})$ in D3 embryonic stem cells. Addition of $80 \mathrm{~nm}$ and $400 \mathrm{~nm}$ aSiNPs to the cell culture medium did not affect the metabolic activity of $\mathrm{D} 3$ cells after exposure for either $24 \mathrm{~h}$ or 10 days. However, the treatments with $10 \mathrm{~nm}$ and $30 \mathrm{~nm}$ aSiNPs for 24 $\mathrm{h}$ remarkably increased the metabolic activity of D3 cells. In contrast, when the treatment was extended to 10 days, exposure to high concentration of the same particles caused a reduction in metabolic activity to $60 \%$ and $57 \%$, respectively. This might be the result of a second burst of nanoparticles being dispersed following the cell culture medium change after three, five, and seven days, finally leading to toxic concentrations. The initial stimulation of metabolic activity after $24 \mathrm{~h}$ of exposure may be an adaptive response of the cell to the nanoparticles. Another research group evaluated the dermal toxicity of aSiNPs with different sizes (7 and 10-20 nm) on cultured HaCaT keratinocytes (CHKs). Both particles decreased cell viability in a dose-dependent manner. However, no difference in cytotoxicity was found between two sizes of aSiNPs, due to the agglomeration of particles and the small difference in hydrodynamic size. ${ }^{85}$ Kim et al ${ }^{86}$ exposed human neuronal cells (SH-SY5Y) to similar sizes of aSiNPs (16.9 nm and $15.3 \mathrm{~nm}$ ). As revealed by MTT assay, there was no significant difference in cytotoxicity with small difference in particle size.

\section{Discussion}

As known, differences in the physical-chemical properties of nanoparticles could cause significant variation in its potential toxicity. ${ }^{87}$ The particle size, as an essential characterization of nanoparticles, could influence the particles' biological reactivity obviously. In general, smaller sized nanoparticles possesses larger surface area as well as higher surface activity, which may make the particles more reactive in biological systems. ${ }^{2}$ Moreover, compared to larger sized nanoparticles, it is easier for smaller nanoparticles to penetrate the cell membrane and induce further damage inside the cells. ${ }^{42}$ However, due to the complexity of the biological system, the results of current reports on the size-dependent toxicity of aSiNPs are not completely consistent. In this systematic review, we explored the relationship between the particle size and cytotoxicity of aSiNPs in vitro, 76 scientific papers were included and the majority of studies tended to demonstrate that smaller sized aSiNPs possessed higher cytotoxicity. However, this size-dependent toxicity could also be influenced by other experimental factors, such as synthetic method of aSiNPs, aggregation state of aSiNPs, experimental conditions, toxicity endpoint detection method and so on.

Amorphous silica particles could be produced by thermal (pyrogenic) or wet routes (colloidal, precipitated and gel). ${ }^{87}$ According to different synthesis conditions and raw materials, the wet route for colloidal silica can be further classified into the Stöber method, Ludox method, and Lysine method, etc. It was reported silanol and siloxane 
were two main groups on the surface of aSiNPs, and the silanol group was more reactive than the siloxane group, moreover, the distribution of these active groups depended on the silica type and the method of synthesis. ${ }^{88}$ Thus, it could be proposed that different synthetic methods varied the surface properties of aSiNPs, which would eventually lead to diverse biological reactivity. ${ }^{89}$ However, Napierska et $\mathrm{al}^{26}$ used two types of silica nanoparticles produced by either Stöber process or Lys-Sil process, with four different diameters $(2,16,60$, and $104 \mathrm{~nm})$, and found the cytotoxicity was related to the particle size directly, which indicated that compared with the synthetic method, the higher surface area of smaller particles played a pivotal role in the enhancement of surface reactivity. Similar results were obtained in the study of Napierska et al, ${ }^{2}$ in which little difference in toxicity was found between Ludox silica nanoparticles (diameters of 14 and $15 \mathrm{~nm}$ ) and Stöber silica nanoparticles $(16 \mathrm{~nm})$. Guichard et $\mathrm{al}^{34}$ used three different types of aSiNPs, which were pyrogenic powder, precipitated powder and precipitated colloid, with the particle sizes ranging from $20-80 \mathrm{~nm}$. The results also showed that the toxicity was strongly associated with the particle sizes. Nevertheless, the authors further observed that pyrogenic and colloidal manufactured aSiNPs of the same size were able to induce DNA damage, while no DNA damage was detected for precipitated particles. Thus, although the toxicity intensity of similar sizes silica particles synthesized in different ways was sometimes similar, the mechanism of toxicity was slightly different. Thomassen et $\mathrm{al}^{37}$ reported that the catalytic ability of hydroxyl radical formation varied with different synthesis methods of aSiNPs. Compared with the lysine method and Stöber method, aSiNPs synthesized using the Ludox method showed higher rate of hydroxyl radical formation and catalytic activity. In summary, the particle size and specific surface area of aSiNPs are still important factors affecting the toxic effects of aSiNPs, but the differences in particle surface chemistry caused by different synthesis methods would also affect the toxic pathways and mechanisms of the particles.

In some cases, aggregation of aSiNPs was observed in cell culture media, which could largely influence the cytotoxicity. Aggregation not only substantially alters the overall characteristics (such as size, shape and surface topology) but also potentially influences the biological outcomes of aSiNPs. $^{23}$ In particular, smaller size of aSiNPs possess extremely large surface area and a huger number of particles in the same mass, consequently having more tendency to aggregate. ${ }^{60}$ By the influence of electron charge and Zeta potential, the suspensions of nanomaterials may be unstable and subsequently promote the aggregation of particles. ${ }^{84}$ Akhtar et $\mathrm{al}^{72}$ reported that the mean of hydrodynamic sizes of $10 \mathrm{~nm}$ and $80 \mathrm{~nm}$ aSiNPs in culture medium, were 352 $\mathrm{nm}$ and $380 \mathrm{~nm}$, respectively. As a result, no significant difference in cytotoxicity between these two sizes of aSiNPs was detected. In the study of Lin et al, ${ }^{71}$ the hydrodynamic sizes of $15 \mathrm{~nm}$ and $46 \mathrm{~nm}$ aSiNPs in water suspension were $590 \pm 104 \mathrm{~nm}$ and $617 \pm 107 \mathrm{~nm}$, respectively; and the decrease of cell viability of the group exposed to $15 \mathrm{~nm}$ aSiNPs was not significantly different from that of $46 \mathrm{~nm}$ aSiNPs. Due to aggregation, the size of nanoparticles was much larger than its original size which means only a small part of nonaggregated particles can penetrate the membrane of cells and produce cytotoxicity. Therefore, original particle size as well as hydrodynamic size should be mentioned in the experiment, which could facilitate the subsequent analysis and comparison of aSiNPs toxicity.

Differences in experimental conditions, such as exposure dose, exposure time, tested cell line, presence of serum, etc, have been proved to affect the toxicity of aSiNPs obviously. Lots of studies in this systematic review have demonstrated the dose- and time-dependent cytotoxic effects caused by aSiNPs. Tokgun et $\mathrm{al}^{23}$ reported that the viability of A549 cells was dose-dependently reduced by all four sizes aSiNPs $(6,15,30$, and $55 \mathrm{~nm})$, examined at 24 $\mathrm{h}$ post-treatment. Wang et al ${ }^{61}$ exposed HEK293 cells to 20 or $50 \mathrm{~nm}$ aSiNPs and observed that the exposure at dosage levels between 20 and $100 \mu \mathrm{g} / \mathrm{mL}$ from 0 to $48 \mathrm{~h}$ decreased the cell viability in both dose- and time-dependent manner. In the study of Ye et al, ${ }^{40} \mathrm{~L}-02$ cells were exposed to 0.2 , 0.4 , and $0.6 \mathrm{mg} / \mathrm{mL}$ of aSiNPs $(21,48$, and $86 \mathrm{~nm})$ for 12 , 24,36 , and $48 \mathrm{~h}$, similar toxicity trends were confirmed as well. It is well known that the number of nanoparticles accumulated around cells or internalized by cells rose gradually with the increased exposure dose, thus contributing more toxic effects on tested cells. ${ }^{40}$ In addition, the exposure time should be another influencing factor of experimental results. Since nanoparticles reached the cytosol of cells by penetration or endocytosis and it took time to induce cytotoxicity, the reduction in survival of cells showed gradually with time. Therefore, longer exposure time of aSiNPs usually causes higher toxicity, as irreparable cell damage accumulates kinetically. ${ }^{70}$

Studies have shown that the toxic reaction of different cell lines to aSiNPs was related to the cellular uptake rate of particles and the reaction mechanism. Du et $\mathrm{al}^{67}$ 
demonstrated that N9 cells (microglia) were more sensitive to the toxicity of aSiNPs than bEnd.3 cells (microendothelial cells) and HT22 cells (neurons), owing to the different uptake rate of aSiNPs. The authors observed that after crossing the blood-brain barrier, aSiNPs were mainly swallowed by N9 cells. However, HT22 cells, a representative model of neurons, were found to barely phagocytize aSiNPs and have minimal cellular uptake of particles. Further research showed that the uptake rate of aSiNPs was closely related to the cellular internalization mode of nanoparticles, and different cell types had different internalization processes. Vicente et $\mathrm{al}^{60}$ found human keratinocytes (K17) showed more intense toxic reactions to aSiNPs than human dermal fibroblasts (HDF), with higher uptake rate of nanoparticles. Moreover, phagocytosis had been identified as the main internalization mechanism for K17, while slower caveolae-mediated endocytosis for HDF. Different cell lines have different reaction mechanisms to aSiNPs, which is also one of the reasons influencing cytotoxicity. Oxidative stress is considered to be an important mechanism of nanomaterial-induced toxicity, leading to the elevated production of ROS, which are directly involved in the regulation of cell survival and death. $^{90,91}$ Passagne et $\mathrm{al}^{68}$ used two proximal tubular cell lines (human HK-2 and porcine LLC-PK1) to investigate the toxic mechanism of aSiNPs. Compared with HK2 cells, LLC-PK1 cells were found to be more susceptible to the toxic effects induced by aSiNPs, and the significantly increased intracellular ROS level was clearly related to the toxicity. After entering the cells, nanoparticles can also stimulate the cells to release cytokines, which are involved in inflammatory processes and further cell structure damage, even cell death. ${ }^{92}$ Låg et a ${ }^{30}$ found that after exposing to aSiNPs, the survival rate of BEAS-2B was lower than that of HBEC3-KT. Moreover, BEAS-2B cells showed much higher cytokine release than HBEC3KT cells, including both IL-6 and CXCL8, which played a central role in inflammatory process induced by particle components. In addition to the above mechanisms, there are also other reaction mechanisms closely related to the toxicity of aSiNPs, such as autophagy dysfunction. The reaction mechanisms may vary from cell to cell, which requires special attention in the analysis of toxic effect of nanoparticles.

The last experimental condition we would like to discuss was the presence of serum in aSiNPs suspension. Due to its high surface reactivity, aSiNPs always absorbs the serum protein leading to the formation of protein shield or protein corona surrounds the particles. It has been well established that the presence of protein corona resulted in surface modification, which further contributed to changes in Zeta potential, aggregation state, cellular uptake, even toxicity. ${ }^{12}$ Lesniak et $\mathrm{al}^{93}$ reported that in the absence of serum, an increased amount of aSiNPs associated with A549 cells was detected and hence an enhanced uptake was postulated. Leibe et $\mathrm{al}^{10}$ analyzed the effects of two sizes of aSiNPs on A549 cells, and found that the cytotoxicity induced by $12 \mathrm{~nm}$ aSiNPs was more pronounced than that of $50 \mathrm{~nm}$ aSiNPs. In addition, both aSiNPs reduced cell viability only in the absence, but not in the presence of serum. Similar phenomenon that serum protein or protein corona reduced the toxicity of aSiNPs was also confirmed by several other investigations. ${ }^{27,69}$ From a mechanistic point of view, researchers suggested different hypotheses of this phenomenon: (1) the formation of protein corona reduced the surface energy of bare aSiNPs; (2) the protein corona decreased the cellular uptake of aSiNPs and thereby the cytotoxic effects were induced to a lesser extent compared to serum free conditions; (3) the presence/absence of protein led to different cellular targeting of aSiNPs. ${ }^{12,22}$ Moreover, for risk assessment with the possibility of threshold dose effects, it is essential to apply the most sensitive conditions. Therefore, serum free condition in addition to serum condition was advised for hazard identification because it demonstrated a higher sensitivity. ${ }^{22}$

Detection method of toxicity endpoint may also influence the results' consistency in different research. The most common endpoint of cytotoxicity was cell viability reduction, which could be reflected by the decrease of mitochondrial activity of tested cells and the increase of lactate dehydrogenase (LDH) release in culture medium. Mitochondria are the energy center of cells, and the mitochondrial activity is closely related to the cell viability. LDH release is an indicator of plasma membrane rupture, which is proportional to the number of cells damaged or lysed. ${ }^{2}$ Several researchers studied the cellular uptake of aSiNPs and pointed out that the transport of smaller particles was dominated by diffusion while larger particles were mainly transported by sedimentation or endocytosis, ${ }^{13}$ which means smaller aSiNPs could easily penetrate cells and induce oxidative reaction to mitochondrial, while larger aSiNPs tended to firstly induce membrane injury through mechanical friction or oxidative damage. ${ }^{94}$ Moreover, it was reported that nanoparticles, owing to their high reactivity, would possibly absorb or interact with the experimental components, leading to 
inaccurate or false results provided by some classical toxicity assays, including MTT and LDH activity assay. ${ }^{95}$ Therefore, in order to ensure the accuracy of experimental results, different toxicity endpoint detection methods should be combined when detecting and comparing the toxic effects induced by aSiNPs with wide range of sizes.

The abovementioned were the main influence factors of size-dependent cytotoxicity of aSiNPs in vitro, which should be taken into consideration when performing relevant studies.

\section{Conclusion}

In the present review, most of the included studies tended to demonstrate that smaller sized aSiNPs with larger surface areas produced higher cytotoxicity. However, there were also some studies that did not reach similar conclusions. As for the influence factors of size-dependent cytotoxicity of aSiNPs in vitro, we mainly expounded from the following four aspects: (1) The synthetic method of aSiNPs could influence the distribution of active groups on the surface of aSiNPs, and further affect the toxic pathways or mechanisms. (2) Aggregation of particles would alter the overall characteristics (size, shape, surface topology, etc) and the cytotoxicity of aSiNPs significantly. Thus, both the original particle size and hydrodynamic size of nanoparticles should be measured in toxicology study. (3) In terms of the influence of different experimental conditions, we mainly discussed exposure dose, exposure time, tested cell line and the presence of serum. A majority of studies reported both dose- and timedependent cytotoxicity of aSiNPs, since higher exposure dose and longer exposure time could increase the cellular uptake of nanoparticles and the interaction duration between particles and cells. The sensitivity of different cell lines to aSiNPs mainly depends on different cellular uptake rate of particles and different reaction mechanisms to the particles. In the presence of serum, aSiNPs could absorb the serum protein and form protein corona, which inhibited its cellular toxicity in most cases. (4) Detection method of toxicity endpoint could influence the toxic effect of aSiNPs from two aspects. Firstly, aSiNPs with different particle sizes might produce toxicity in different subcellular structures. Secondly, nanoparticles owing to its high reactivity would possibly absorb or interact with the experimental components, leading to inaccurate or false results. Therefore, two or more kinds of toxicity endpoint detection methods should be combined in nanotoxicology study.
In addition to the above influence factors, the current studies on toxicity of aSiNPs still have some limitations, which should also be taken into account in future experimental research. Most included investigations in this review did not use a specific guideline to carry out their experiments, causing some diversity of experimental details and difficulties in quantitative comparison between studies. Thus, it is recommended to apply a certain guideline, which can largely improve the comparability of different studies and the control of systematic bias. ${ }^{96}$ Another insufficiency was that some researchers used very high dosage in their toxicity and mechanism studies, which was far beyond the actual exposure dose of occupational population or general population. Hence, it is inappropriate and not recommended to use extremely high dosage in a nanotoxicology study in vitro. Lastly, although adverse effects of aSiNPs observed in vitro might indicate toxicity in vivo, follow-up investigations are needed to confirm this relationship. Moreover, evidence on population exposure data and potential effect of aSiNPs in human beings is still insufficient and needs to be explored further. Therefore, it is of great significance to conduct more studies on the toxicity of aSiNPs both in vitro and in vivo, and related adverse effects on human health should get more attention.

\section{Acknowledgments}

This work was supported by the National Natural Science Foundation of China (81930091, 91943301, and $81602875)$ and National Key Research and Development Program of China (2017YFC0211600, 2017YFC0211602, 2017YFC0211606).

\section{Disclosure}

The authors report no conflicts of interest in this work.

\section{References}

1. Turci F, Pavan C, Leinardi R, et al. Revisiting the paradigm of silica pathogenicity with synthetic quartz crystals: the role of crystallinity and surface disorder. Part Fibre Toxicol. 2016;13(1):32. doi:10.1186/ s12989-016-0136-6

2. Napierska D, Thomassen LC, Rabolli V, et al. Size-dependent cytotoxicity of monodisperse silica nanoparticles in human endothelial cells. Small. 2009;5(7):846-853. doi:10.1002/smll.200800461

3. Kamikubo Y, Yamana T, Hashimoto $Y$, Sakurai $T$. Induction of oxidative stress and cell death in neural cells by silica nanoparticles. ACS Chem Neurosci. 2019;10(1):304-312. doi:10. 1021/acschemneuro.8b00248

4. Vance ME, Kuiken T, Vejerano EP, et al. Nanotechnology in the real world: redeveloping the nanomaterial consumer products inventory. Beilstein J Nanotechnol. 2015;6:1769-1780. doi:10.3762/bjnano.6.181 
5. WHO. Guidelines on Protecting Workers from Potential Risks of Manufactured Nanomaterials. Geneva: World Health Organization; 2017.

6. Yazdimamaghani M, Moos PJ, Dobrovolskaia MA, Ghandehari H. Genotoxicity of amorphous silica nanoparticles: status and prospects. Nanomedicine. 2019;16:106-125. doi:10.1016/j.nano.2018.11.013

7. Al Faraj A, Alotaibi B, Shaik AP, Shamma KZ, Al Jammaz I, Gerl J. Sodium-22-radiolabeled silica nanoparticles as new radiotracer for biomedical applications: in vivo positron emission tomography imaging, biodistribution, and biocompatibility. Int $J$ Nanomedicine. 2015;10:6293-6302. doi:10.2147/IJN.S93523

8. Guo M, Xu X, Yan X, Wang S, Gao S, Zhu S. In vivo biodistribution and synergistic toxicity of silica nanoparticles and cadmium chloride in mice. J Hazard Mater. 2013;260:780-788. doi:10.1016/j.jhazmat.2013.06.040

9. Li Y, Yu Y, Duan J, et al. The internalization, distribution, and ultrastructure damage of silica nanoparticles in human hepatic L-02 cells. Part Part Syst Charact. 2016;33(9):664-674. doi:10.1002/ppsc.201600043

10. Leibe R, Hsiao IL, Fritsch-Decker S, et al. The protein corona suppresses the cytotoxic and pro-inflammatory response in lung epithelial cells and macrophages upon exposure to nanosilica. Arch Toxicol. 2019;93(4):871-885. doi:10.1007/s00204-019-02422-9

11. Li Y, Ma R, Liu X, et al. Endoplasmic reticulum stress-dependent oxidative stress mediated vascular injury induced by silica nanoparticles in vivo and in vitro. NanoImpact. 2019;14:100169. doi:10.1016/j. impact.2019.100169

12. Saikia J, Yazdimamaghani M, Hadipour Moghaddam SP, Ghandehari H. Differential protein adsorption and cellular uptake of silica nanoparticles based on size and porosity. ACS Appl Mater Interfaces. 2016;8(50):34820-34832. doi:10.1021/acsami.6b09950

13. Kim W, Kim WK, Lee K, et al. A reliable approach for assessing size-dependent effects of silica nanoparticles on cellular internalization behavior and cytotoxic mechanisms. Int $J$ Nanomedicine. 2019;14:7375-7387. doi:10.2147/IJN.S224183

14. Murugadoss S, van den Brule S, Brassinne F, et al. Is aggregated synthetic amorphous silica toxicologically relevant? Part Fibre Toxicol. 2020;17(1):1. doi:10.1186/s12989-019-0331-3

15. Wang W, Zeng C, Feng Y, et al. The size-dependent effects of silica nanoparticles on endothelial cell apoptosis through activating the p53-caspase pathway. Environ Pollut. 2018;233:218-225. doi:10.1016/j. envpol.2017.10.053

16. Lee K, Lee J, Kwak M, et al. Two distinct cellular pathways leading to endothelial cell cytotoxicity by silica nanoparticle size. J Nanobiotechnology. 2019;17(1):24. doi:10.1186/s12951-019-0456-4

17. Freese C, Schreiner D, Anspach L, et al. In vitro investigation of silica nanoparticle uptake into human endothelial cells under physiological cyclic stretch. Part Fibre Toxicol. 2014;11:68. doi:10.1186/ s12989-014-0068-y

18. Nishijima N, Hirai T, Misato $\mathrm{K}$, et al. Human scavenger receptor A1-mediated inflammatory response to silica particle exposure is size specific. Front Immunol. 2017;8:379. doi:10.3389/fimmu.2017.00379

19. Samuel GO, Hoffmann S, Wright RA, et al. Guidance on assessing the methodological and reporting quality of toxicologically relevant studies: a scoping review. Environ Int. 2016;92:630-646. doi:10.1016/j.envint.2016.03.010

20. Gonzalez L, Thomassen LC, Plas G, et al. Exploring the aneugenic and clastogenic potential in the nanosize range: A549 human lung carcinoma cells and amorphous monodisperse silica nanoparticles as models. Nanotoxicology. 2010;4:382-395. doi:10.3109/17435390.2010.501913

21. Fede C, Millino C, Pacchioni B, et al. Altered gene transcription in human cells treated with Ludox ${ }^{\circledR}$ silica nanoparticles. Int J Environ Res Public Health. 2014;11(9):8867-8890. doi:10.3390/ijerph110908867

22. Gonzalez L, Lukamowicz-Rajska M, Thomassen LC, et al. Coassessment of cell cycle and micronucleus frequencies demonstrates the influence of serum on the in vitro genotoxic response to amorphous monodisperse silica nanoparticles of varying sizes. Nanotoxicology. 2014;8(8):876-884. doi:10.3109/17435390.2013.842266
23. Tokgun O, Demiray A, Kaya B, et al. Silica nanoparticles can induce apoptosis via dead receptor and caspase 8 pathway on A549 cells. Adv Food Sci. 2015;37:65-70.

24. Liu W, Hu T, Zhou L, et al. Nrf2 protects against oxidative stress induced by $\mathrm{SiO} 2$ nanoparticles. Nanomedicine (Lond). 2017;12 (19):2303-2318. doi:10.2217/nnm-2017-0046

25. Wottrich R, Diabaté S, Krug HF. Biological effects of ultrafine model particles in human macrophages and epithelial cells in mono- and co-culture. Int J Hyg Environ Health. 2004;207(4):353-361. doi:10. 1078/1438-4639-00300

26. Napierska D, Thomassen LC, Vanaudenaerde B, et al. Cytokine production by co-cultures exposed to monodisperse amorphous silica nanoparticles: the role of size and surface area. Toxicol Lett. 2012;211 (2):98-104. doi:10.1016/j.toxlet.2012.03.002

27. Panas A, Marquardt C, Nalcaci O, et al. Screening of different metal oxide nanoparticles reveals selective toxicity and inflammatory potential of silica nanoparticles in lung epithelial cells and macrophages. Nanotoxicology. 2012;7(3):259-273. doi:10.3109/17435390.2011.652206

28. Li Q, Hu H, Jiang L, Zou Y, Duan J, Sun Z. Cytotoxicity and autophagy dysfunction induced by different sizes of silica particles in human bronchial epithelial BEAS-2B cells. Toxicol Res (Camb). 2016;5(4):1216-1228. doi:10.1039/c6tx00100a

29. Li Y, Duan J, Chai X, et al. Microarray-assisted size-effect study of amorphous silica nanoparticles on human bronchial epithelial cells. Nanoscale. 2019;11(47):22907-22923. doi:10.1039/c9nr07350g

30. Låg M, Skuland T, Godymchuk A, Nguyen THT, Pham HLT, Refsnes M. Silica nanoparticle-induced cytokine responses in BEAS-2B and HBEC3-KT cells: significance of particle size and signalling pathways in different lung cell cultures. Basic Clin Pharmacol Toxicol. 2018;122(6):620-632. doi:10.1111/bcpt.12963

31. Kasper J, Hermanns MI, Bantz C, et al. Interactions of silica nanoparticles with lung epithelial cells and the association to flotillins. Arch Toxicol. 2013;87(6):1053-1065. doi:10.1007/s00204-012-0876-5

32. McCarthy J, Inkielewicz-Stępniak I, Corbalan JJ, Radomski MW. Mechanisms of toxicity of amorphous silica nanoparticles on human lung submucosal cells in vitro: protective effects of fisetin. Chem Res Toxicol. 2012;25(10):2227-2235. doi:10.1021/tx3002884

33. Xu Z, Chou L, Sun J. Effects of $\mathrm{SiO} 2$ nanoparticles on HFL-I activating ROS-mediated apoptosis via p53 pathway. $\mathrm{J} \mathrm{Appl}$ Toxicol. 2012;32(5):358-364. doi:10.1002/jat.1710

34. Guichard Y, Fontana C, Chavinier E, et al. Cytotoxic and genotoxic evaluation of different synthetic amorphous silica nanomaterials in the V79 cell line. Toxicol Ind Health. 2016;32(9):1639-1650. doi: $10.1177 / 0748233715572562$

35. Corbalan JJ, Medina C, Jacoby A, Malinski T, Radomski MW. Amorphous silica nanoparticles trigger nitric oxide/peroxynitrite imbalance in human endothelial cells: inflammatory and cytotoxic effects. Int J Nanomedicine. 2011;6:2821-2835. doi:10.2147/IJN.S25071

36. Nemmar A, Albarwani S, Beegam S, et al. Amorphous silica nanoparticles impair vascular homeostasis and induce systemic inflammation. Int J Nanomedicine. 2014;9:2779-2789. doi:10.2147/IJN.S52818

37. Thomassen LC, Aerts A, Rabolli V, et al. Synthesis and characterization of stable monodisperse silica nanoparticle sols for in vitro cytotoxicity testing. Langmuir. 2010;26(1):328-335. doi:10.1021/la902050k

38. Napierska D, Rabolli V, Thomassen LC, et al. Oxidative stress induced by pure and iron-doped amorphous silica nanoparticles in subtoxic conditions. Chem Res Toxicol. 2012;25(4):828-837. doi:10.1021/tx200361v

39. Ye Y, Liu J, Chen M, Sun L, Lan M. In vitro toxicity of silica nanoparticles in myocardial cells. Environ Toxicol Pharmacol. 2010;29(2):131-137. doi:10.1016/j.etap.2009.12.002

40. Ye Y, Liu J, Xu J, Sun L, Chen M, Lan M. Nano-SiO2 induces apoptosis via activation of p53 and Bax mediated by oxidative stress in human hepatic cell line. Toxicol in Vitro. 2010;24(3):751-758. doi:10.1016/j.tiv.2010.01.001 
41. Xue Y, Chen Q, Ding T, Sun J. $\mathrm{SiO}_{2}$ nanoparticle-induced impairment of mitochondrial energy metabolism in hepatocytes directly and through a Kupffer cell-mediated pathway in vitro. Int $J$ Nanomedicine. 2014;9:2891-2903. doi:10.2147/IJN.S60661

42. Li Y, Sun L, Jin M, et al. Size-dependent cytotoxicity of amorphous silica nanoparticles in human hepatoma HepG2 cells. Toxicol in Vitro. 2011;25(7):1343-1352. doi:10.1016/j.tiv.2011.05.003

43. Tarantini A, Lanceleur R, Mourot A, et al. Toxicity, genotoxicity and proinflammatory effects of amorphous nanosilica in the human intestinal Caco-2 cell line. Toxicol in Vitro. 2015;29(2):398-407. doi:10.1016/j.tiv.2014.10.023

44. Gehrke H, Frühmesser A, Pelka J, et al. In vitro toxicity of amorphous silica nanoparticles in human colon carcinoma cells. Nanotoxicology. 2013;7(3):274-293. doi:10.3109/17435390.2011.652207

45. Fritsch-Decker S, An Z, Yan J, et al. Silica nanoparticles provoke cell death independent of p53 and BAX in human colon cancer cells. Nanomaterials (Basel). 2019;9(8):1172. doi:10.3390/nano9081172

46. Waters KM, Masiello LM, Zangar RC, et al. Macrophage responses to silica nanoparticles are highly conserved across particle sizes. Toxicol Sci. 2009;107(2):553-569. doi:10.1093/toxsci/kfn250

47. Nabeshi H, Yoshikawa T, Akase T, et al. Effect of amorphous silica nanoparticles on in vitro RANKL-induced osteoclast differentiation in murine macrophages. Nanoscale Res Lett. 2011;6(1):464. doi:10.1186/1556-276X-6-464

48. Kim S, Jang J, Kim H, Choi H, Lee K, Choi IH. The effects of silica nanoparticles in macrophage cells. Immune Netw. 2012;12 (6):296-300. doi:10.4110/in.2012.12.6.296

49. Premshekharan G, Nguyen K, Zhang H, Forman HJ, Leppert VJ. Low dose inflammatory potential of silica particles in human-derived THP-1 macrophage cell culture studies - Mechanism and effects of particle size and iron. Chem Biol Interact. 2017;272:160-171. doi:10.1016/j.cbi.2017.05.004

50. Kusaka T, Nakayama M, Nakamura K, Ishimiya M, Furusawa E, Ogasawara K. Effect of silica particle size on macrophage inflammatory responses. PLoS One. 2014;9(3):e92634. doi:10.1371/journal. pone. 0092634

51. Mendoza A, Torres-Hernandez JA, Ault JG, Pedersen-Lane JH, Gao D, Lawrence DA. Silica nanoparticles induce oxidative stress and inflammation of human peripheral blood mononuclear cells. Cell Stress Chaperones. 2014;19(6):777-790. doi:10.1007/s12192-0140502-y

52. Nakanishi K, Tsukimoto M, Tanuma S, Takeda K, Kojima S. Silica nanoparticles activate purinergic signaling via $\mathrm{P} 2 \mathrm{X} 7$ receptor in dendritic cells, leading to production of pro-inflammatory cytokines. Toxicol in Vitro. 2016;35:202-211. doi:10.1016/j. tiv.2016.06.003

53. Kojima S, Negishi Y, Tsukimoto M, Takenouchi T, Kitani H, Takeda K. Purinergic signaling via P2X7 receptor mediates IL-1 $\beta$ production in Kupffer cells exposed to silica nanoparticle. Toxicology. 2014;321:13-20. doi:10.1016/j.tox.2014.03.008

54. Yang X, Liu J, He H, et al. $\mathrm{SiO} 2$ nanoparticles induce cytotoxicity and protein expression alteration in HaCaT cells. Part Fibre Toxicol. 2010;7:1. doi:10.1186/1743-8977-7-1

55. Gong C, Tao G, Yang L, Liu J, He H, Zhuang Z. The role of reactive oxygen species in silicon dioxide nanoparticle-induced cytotoxicity and DNA damage in HaCaT cells. Mol Biol Rep. 2012;39(4):49154925. doi:10.1007/s11033-011-1287-z

56. Nabeshi H, Yoshikawa T, Matsuyama K, et al. Amorphous nanosilica induce endocytosis-dependent ROS generation and DNA damage in human keratinocytes. Part Fibre Toxicol. 2011;8:1. doi:10.1186/ 1743-8977-8-1

57. Nagakura $C$, Negishi Y, Tsukimoto $M$, et al. Involvement of P2Y11 receptor in silica nanoparticles 30-induced IL-6 production by human keratinocytes. Toxicology. 2014;322:61-68. doi:10.1016/j.tox.2014.03. 010
58. Gong C, Yang L, Zhou J, Guo X, Zhuang Z. Possible role of PAPR-1 in protecting human $\mathrm{HaCaT}$ cells against cytotoxicity of $\mathrm{SiO} 2$ nanoparticles. Toxicol Lett. 2017;280:213-221. doi:10.1016/j. toxlet.2017.07.213

59. Yu K, Grabinski C, Schrand A, et al. Toxicity of amorphous silica nanoparticles in mouse keratinocytes. $J$ Nanoparticle Res. 2009;11:15-24. doi:10.1007/s11051-008-9417-9

60. Vicente S, Moia $\mathrm{C}$, Zhu H, Vigé X. In vitro evaluation of the internalization and toxicological profile of silica nanoparticles and submicroparticles for the design of dermal drug delivery strategies. J Appl Toxicol. 2017;37(12):1396-1407. doi:10.1002/ jat.3507

61. Wang F, Gao F, Lan M, Yuan H, Huang Y, Liu J. Oxidative stress contributes to silica nanoparticle-induced cytotoxicity in human embryonic kidney cells. Toxicol in Vitro. 2009;23(5):808-815. doi:10.1016/j.tiv.2009.04.009

62. Manganelli S, Leone C, Toropov AA, Toropova AP, Benfenati E. QSAR model for predicting cell viability of human embryonic kidney cells exposed to $\mathrm{SiO}_{2}$ nanoparticles. Chemosphere. 2016;144:995-1001. doi:10.1016/j.chemosphere.2015.09.086

63. Wang F, Jiao C, Liu J, Yuan H, Lan M, Gao F. Oxidative mechanisms contribute to nanosize silicon dioxide-induced developmental neurotoxicity in PC12 cells. Toxicol in Vitro. 2011;25(8):1548-1556. doi:10.1016/j.tiv.2011.05.019

64. Yuan H, Gao F, Zhang Z, et al. Study on controllable preparation of silica nanoparticles with multi-sizes and their size-dependent cytotoxicity in pheochromocytoma cells and human embryonic kidney cells. J Health Sci. 2010;56:632-640. doi:10.1248/jhs.56.632

65. Ariano P, Zamburlin P, Gilardino A, et al. Interaction of spherical silica nanoparticles with neuronal cells: size-dependent toxicity and perturbation of calcium homeostasis. Small. 2011;7(6):766-774. doi:10.1002/smll.201002287

66. Kim JE, Kim H, An SS, Maeng EH, Kim MK, Song YJ. In vitro cytotoxicity of $\mathrm{SiO} 2$ or $\mathrm{ZnO}$ nanoparticles with different sizes and surface charges on U373MG human glioblastoma cells. Int $J$ Nanomedicine. 2014;9(Suppl2):235-241. doi:10.2147/IJN.S57936

67. Du Q, Ge D, Mirshafiee V, et al. Assessment of neurotoxicity induced by different-sized Stöber silica nanoparticles: induction of pyroptosis in microglia. Nanoscale. 2019;11(27):12965-12972. doi:10.1039/ c9nr03756j

68. Passagne I, Morille M, Rousset M, Pujalté I, L'azou B. Implication of oxidative stress in size-dependent toxicity of silica nanoparticles in kidney cells. Toxicology. 2012;299(2-3):112-124. doi:10.1016/j. tox.2012.05.010

69. Al-Rawi M, Diabaté S, Weiss C. Uptake and intracellular localization of submicron and nano-sized $\mathrm{SiO}_{2}$ particles in HeLa cells. Arch Toxicol. 2011;85(7):813-826. doi:10.1007/s00204-010-0642-5

70. Vo NT, Bufalino MR, Hartlen KD, Kitaev V, Lee LE. Cytotoxicity evaluation of silica nanoparticles using fish cell lines. Vitro Cell Dev Biol Anim. 2014;50(5):427-438. doi:10.1007/s11626-0139720-3

71. Lin W, Huang YW, Zhou XD, Ma Y. In vitro toxicity of silica nanoparticles in human lung cancer cells. Toxicol Appl Pharmacol. 2006;217(3):252-259. doi:10.1016/j.taap.2006.10.004

72. Akhtar MJ, Ahamed M, Kumar S, et al. Nanotoxicity of pure silica mediated through oxidant generation rather than glutathione depletion in human lung epithelial cells. Toxicology. 2010;276(2):95-102. doi:10.1016/j.tox.2010.07.010

73. Horie M, Nishio K, Kato H, et al. Evaluation of cellular effects of silicon dioxide nanoparticles. Toxicol Mech Methods. 2014;24 (3):196-203. doi:10.3109/15376516.2013.879505

74. Gualtieri M, Skuland T, Iversen TG, et al. Importance of agglomeration state and exposure conditions for uptake and pro-inflammatory responses to amorphous silica nanoparticles in bronchial epithelial cells. Nanotoxicology. 2012;6(7):700-712. doi:10.3109/17435390.2011.60 4441 
75. Bauer AT, Strozyk EA, Gorzelanny C, et al. Cytotoxicity of silica nanoparticles through exocytosis of von Willebrand factor and necrotic cell death in primary human endothelial cells. Biomaterials. 2011;32(33):8385-8393. doi:10.1016/j.biomaterials.2011.07.078

76. Wang DP, Wang ZJ, Zhao R, et al. Silica nanomaterials induce organ injuries by $\mathrm{Ca} 2+-\mathrm{ROS}$-initiated disruption of the endothelial barrier and triggering intravascular coagulation. Part Fibre Toxicol. 2020;17 (1):12. doi:10.1186/s12989-020-00340-8

77. Lu X, Qian J, Zhou H, et al. In vitro cytotoxicity and induction of apoptosis by silica nanoparticles in human HepG2 hepatoma cells. Int J Nanomedicine. 2011;6:1889-1901. doi:10.2147/IJN.S24005

78. Docter D, Bantz C, Westmeier D, et al. The protein corona protects against size- and dose-dependent toxicity of amorphous silica nanoparticles. Beilstein J Nanotechnol. 2014;5:1380-1392. doi:10.3762/ bjnano.5.151

79. Morishige T, Yoshioka Y, Inakura H, et al. Cytotoxicity of amorphous silica particles against macrophage-like THP-1 cells depends on particle-size and surface properties. Pharmazie. 2010;65(8):596-599.

80. Gazzano E, Ghiazza M, Polimeni M, et al. Physicochemical determinants in the cellular responses to nanostructured amorphous silicas. Toxicol Sci. 2012;128(1):158-170. doi:10.1093/toxsci/ kfs 128

81. Stępnik M, Arkusz J, Smok-Pieniążek A, et al. Cytotoxic effects in 3T3-L1 mouse and WI-38 human fibroblasts following 72 hour and 7 day exposures to commercial silica nanoparticles. Toxicol Appl Pharmacol. 2012;263(1):89-101. doi:10.1016/j.taap.2012.06.002

82. Uboldi C, Giudetti G, Broggi F, Gilliland D, Ponti J, Rossi F. Amorphous silica nanoparticles do not induce cytotoxicity, cell transformation or genotoxicity in Balb/3T3 mouse fibroblasts. Mutat Res. 2012;745(1-2):11-20. doi:10.1016/j.mrgentox.2011.10.010

83. Kim IY, Joachim E, Choi H, Kim K. Toxicity of silica nanoparticles depends on size, dose, and cell type. Nanomedicine. 2015;11 (6):1407-1416. doi:10.1016/j.nano.2015.03.004

84. Park MV, Annema W, Salvati A, et al. In vitro developmental toxicity test detects inhibition of stem cell differentiation by silica nanoparticles. Toxicol Appl Pharmacol. 2009;240(1):108-116. doi:10.1016/j.taap.2009.07.019

85. Park YH, Kim JN, Jeong SH, et al. Assessment of dermal toxicity of nanosilica using cultured keratinocytes, a human skin equivalent model and an in vivo model. Toxicology. 2010;267(1-3):178-181. doi:10.1016/j.tox.2009.10.011
86. Kim YJ, Yu M, Park HO, Yang SI. Comparative study of cytotoxicity, oxidative stress and genotoxicity induced by silica nanomaterials in human neuronal cell line. Mol Cell Toxicol. 2010;6:336-343. doi:10.1007/s13273-010-0045-y

87. Murugadoss S, Lison D, Godderis L, et al. Toxicology of silica nanoparticles: an update. Arch Toxicol. 2017;91(9):2967-3010. doi:10.1007/s00204-017-1993-y

88. OECD. Series on the safety of manufactured nanomaterials no. 71: silicon dioxide: summary of the dossier. OECD. 2016.

89. Napierska D, Thomassen LC, Lison D, Martens JA, Hoet PH. The nanosilica hazard: another variable entity. Part Fibre Toxicol. 2010;7 (1):39. doi:10.1186/1743-8977-7-39

90. Fu PP, Xia Q, Hwang HM, Ray PC, Yu H. Mechanisms of nanotoxicity: generation of reactive oxygen species. J Food Drug Anal. 2014;22(1):64-75. doi:10.1016/j.jfda.2014.01.005

91. Petrache Voicu SN, Dinu D, Sima C, et al. Silica nanoparticles induce oxidative stress and autophagy but not apoptosis in the MRC-5 cell line. Int $J$ Mol Sci. 2015;16(12):29398-29416. doi:10.3390/ ijms 161226171

92. Voicu SN, Balas M, Stan MS, et al. Amorphous silica nanoparticles obtained by laser ablation induce inflammatory response in human lung fibroblasts. Materials (Basel). 2019;12(7):1026. doi:10.3390/ ma12071026

93. Lesniak A, Fenaroli F, Monopoli MP, Åberg C, Dawson KA, Salvati A. Effects of the presence or absence of a protein corona on silica nanoparticle uptake and impact on cells. ACS Nano. 2012;6 (7):5845-5857. doi:10.1021/nn300223w

94. Faklaris O, Joshi V, Irinopoulou T, et al. Photoluminescent diamond nanoparticles for cell labeling: study of the uptake mechanism in mammalian cells. ACS Nano. 2009;3(12):3955-3962. doi:10.1021/ $\mathrm{nn} 901014 \mathrm{j}$

95. Monteiro-Riviere NA, Inman AO, Zhang LW. Limitations and relative utility of screening assays to assess engineered nanoparticle toxicity in a human cell line. Toxicol Appl Pharmacol. 2009;234 (2):222-235. doi:10.1016/j.taap.2008.09.030

96. Faria M, Björnmalm M, Thurecht KJ, et al. Minimum information reporting in bio-nano experimental literature. Nat Nanotechnol. 2018;13(9):777-785. doi:10.1038/s41565-018-0246-4
International Journal of Nanomedicine

\section{Publish your work in this journal}

The International Journal of Nanomedicine is an international, peerreviewed journal focusing on the application of nanotechnology in diagnostics, therapeutics, and drug delivery systems throughout the biomedical field. This journal is indexed on PubMed Central, MedLine, CAS, SciSearch ${ }^{\mathbb{R}}$, Current Contents ${ }^{\mathbb{B}} /$ Clinical Medicine,
Journal Citation Reports/Science Edition, EMBase, Scopus and the Elsevier Bibliographic databases. The manuscript management system is completely online and includes a very quick and fair peer-review system, which is all easy to use. Visit http://www.dovepress.com/ testimonials.php to read real quotes from published authors. 